\title{
Le tolérantisme musical - komentarji k študiji Antoinea Bemetzriederja o nacionalnih glasbenih kulturah v 18. stoletju. Pripombe k spoznavoslovju glasbe

\author{
Le tolérantisme musical - Comments on
} \\ Antoine Bemetzrieder's Essay on National Musical Cultures in the 18th century. Notes on the Epistemology of Music
}

Ključne besede: Antoine Bemetzrieder, spoznavoslovje raziskovanja glasbe, sociologija glasbe, anthropology of music, toleranca

IZVLEČEK

Prispevek prinaša komentirani prevod publikacije Antoinea Bemetzriederja Le tolérantisme musical (1779). Njegov spis skozi diskusijo o treh glavnih glasbenih kulturah Evrope in prevladi ene (italijanske nad nemško in francosko) v enaki meri razkriva sociološke koordinate nacionalne identitete glasbev 18. stoletju (in ponuja pragmatično "pravo rešitev« vprašanja nacionalne glasbe: postavitev nacionalne francoske opere) kakor tudi ponuja pomembne spoznavoslovne iztočnice raziskovanja glasbe, ki so tudi danes vredne upoštevanja. Komentarji k prevodu se nanašajo na spoznavoslovne iztočnice, puščajoč ob strani za ta spis sicer zgodovinsko pomembne vsebine.
Keywords: Antoine Bemetzrieder, the epistemology of music research, the sociology of music, the anthropology of music, tolerance

ABSTRACT

The essay is conceived of as a set of comments on Le tolérantisme musical by Antoine Bemetzrieder. His text, published in 1779, discusses the three main European musical cultures and the hierarchy among them (Italian hegemony over German and French music). While reflecting on the reasons for this, Bemetzrieder reveals the sociological coordinates of identifying the national imprint in the music of the 18th century (offering a pragmatic solution to the "right solution" regarding Italian hegemony: the establishment the French National Opera House) while at the same time offering epistemological premises that deserve contemporary musicological attention. The comments added to the translation of Bemetzrieder's text relate to epistemological issues contained within it, leaving aside the historically important content so crucial for the text. 
Antoine Bemetzrieder, leta 1739 rojeni alzaški Francoz, ki je Pariz zapustil leta 1781 in odšel v London, kjer je umrl po letu 1808 (in pred 1817), je v učbenikih zgodovine komajda kdaj omenjeno ime. (V glavnih nemških glasbenozgodovinskih učbenikih zadnjih sto let sploh ni omenjen.) Poleg svojih pedagoško učinkovito zasnovanih glasbenoteoretskih del, med katerimi leksika opozarja na Leçons de clavicen et principes d'harmonie (1771, španski prevod je sledil 1775, angleški pa 1778), je danes znan predvsem kot učitelj klavirja hčere enciklopedista Denisa Diderota. Čeprav bi Bemetzriederjev pogled na glasbeno izobraževanje verjetno tudi danes zbudil pozornost zaradi učinkovite metodološke zasnove in celostnega pojmovanja učenja glasbene, razmeroma skopi podatki o njegovem življenju in delu poleg navedenega spisa omenjajo zlasti knjižico z naslovom Glasbena toleranca (Le tolérantisme musical) iz leta 1779. Ta sodi v obnebje francoskih glasbeno-nazorskih »querels«s sredine 18. stoletja, ki so dve desetletji po smrti pariškega kardinala italijanskega porekla Julesa Mazarina ${ }^{1}$ leta 1661, ko so bili italijanski glasbeniki prisiljeni zapustiti Francijo in so ponovno pridobili naklonjenost francoske javnosti s smrtjo osrednjega francoskega mojstra tistega časa, J. B. Lullyja (1632-1687). Sodi torej v obnebje, ko je leta 1672 ustanovljena Académie Royale de Musique (sicer mimo vrste drugih imen danes znana kot Opéra) predstavljala nosilko (resda ne edino ...) pariške glasbe, ki so jo dve leti po Napoleonovem dekretu iz leta 1793 - (8. avgust, §.1): »Toutes les académies et sociétés littéraires patentées ou dotées par la Nation, sont supprimées « ${ }^{2}$ vključili v Institut national des Sciences et des Arts (danes del Institut de France).

Glede tematike Bemetzriederjevega spisa je mogoče reči, da ostaja tehtno muzikološko pričevanje o času, ki vsaj iz dveh razlogov sega do nas. Ne obravnava le vprašanje soobstoja glasbenoestetskih strankarskih trenj, katerih »nacional(isti)no« predzgodovino zgovorno povzema Jean-Jacques Rousseau: »Pravijo, da so Bernierove kantate nekega francoskega glasbenika ozdravile mrzlice; pri glasbeniku vsakega drugega naroda bi jo verjetno povzročile. $\aleph^{3}$ Poleg pričevanja o estetskih navzkrižjih, ki jih je vključno z današnjimi smiselno razumeti ne le kot pomembno glasbenozgodovinsko, temveč tudi spoznavoslovno tematiko, pa Bemetzriederjev spis ponuja tudi za danšnji čas aktualno refleksijo o spoznavnih koordinatah družboslovnega utemeljevanja glasbene identitete.

Zato prispevek prinaša prevod Glasbene tolerance - zaradi terminoloških specifik skupaj z izvirnikom celotnega Bemetzriederjevega besedila -, ki ga spremljajo vstavljeni komentarji. ${ }^{4}$ Čeprav izhajajo iz Bemetzriederjevega besedila, vstavljeni komentarji niso vezani na razlago podrobnosti, ki jih avtor ponuja v premislek, pa tudi ne merijo na razlago zgodovinskih okoliščin, ki so pomembne za razumevanje tega spisa: ne gre za kritični prevod v klasičnem pomenu besede, pač pa za premislek o nekaterih iztočnicah, ki se jih loteva Bemetzrieder v Glasbeni toleranci. Med temi je osrednje Bemetzriederjevo iskanje "prave rešitve« v razpravljanju o treh glasbenih »strankah« ali

Rojen 1602 in krščen kot Guilio Raimondo Mazzarino.

2 Navedeno po: Institut national. V: Ferdinand Buisson. Noveau dictionnaire de pédagogie. Paris. Libraire Hachette, 1911, elektronska verzija (dostop 1.7.2007): http://www.inrp.fr/edition-electronique/lodel/dictionnaire-ferdinand-buisson/document. php?id=2925.

3 Jean Jacques Rouseauj. Esej o izvoru jezikov, v katerem se govori o melodiji in glasbenem posnemanju. Ljubljana: Temeljna dela, $1999,57$.

4 Čeprav je moj prevod lektorirala in jezikovno temeljito pregledala Albina Škerbinc, gre za ohranjene nerodnosti kriviti samo mene (L. S.). Izvirnik nosi naslednje podatke: Le tolérantisme musical / Par M. Bemetzrieder / A paris, / Chez l'Auteur, rue Neuve-Saint-Roch, près celle des Moineaux. / Et chez ONFROY, Libreaire, Quai des Augustins au Lys d'Or. / 1779. 
"sektah" - o gluckistih, piccinistih in ljubiteljih francoske glasbe -, ki se na primerljiv način pojavlja v sodobni muzikološki preobleki. Morda je manj izrazito na neki splošno uveljavljeni disciplinarni ravni in obstaja predvsem v obliki razpršene vrste idej, konceptov in načinov sistematiziranja podatkov in argumentiranja dejstev, toda vprašanje "pravega« raziskovanja glasbe je v zadnjih dveh desetletjih dobilo vsekakor omembe vredno pozornost znotraj stroke.

Izhodiščno stališče celotnega prispevka je naslednje. V močno poenostavljeni obliki, ki bi jo bilo treba sicer veliko podrobneje komentirati kot je to storjeno na tem mestu, je mogoče iskati zgolj "prava«, torej različna muzikološka področja in ne enega: med različnimi krogi, šolami, tradicijami raziskovanja, stališči ipd. »Predstavnike« je mogoče, v duhu pluralizma pojavov, »klasificirati« na različne načine. Kljub temu pa se zdita po pogostosti in pomenu izrekanj morda osrednji, med seboj tesno povezani, a vendarle dovolj jasno profilirani ločnici raziskovalnih usmeritev naslednji: na eni strani je mogoče govoriti o raziskovalnih usmeritvah, ki sledijo določenim spoznavoslovnim in metodološkim načelom, medtem ko po drugi strani kaže iskati stične točke v osredotočenosti na posamezne slogovne danosti, še pogosteje na časovna obdobja. Ločnica torej nastaja iz razlike med sredobežnimi »relacijami« na prvi strani in sredotežnimi "substancami« na drugi. Če je za prvo stran mogoče najti številna pričevanja denimo v zadnjih dveh desetletjih modni in danes nemara povsem korektno zgodovinopisno imenovani »Novi muzikologiji« (New/Critical/Cultural Musicology) ali pa v empirično, najsi naravoslovno ali družboslovno usmerjenih raziskavah, ${ }^{5}$ je za drugo stran mogoče navesti denimo okrepljeno ločevanje raziskovanja po pozameznih zvrsteh ali slogih, pri čemer gre za pragmatične, nikakor stvarno utemeljene razlike tipa: resna glasba - ljudska glasba - stara glasba - moderna glasba - popularna glasba - glasbe sveta. ${ }^{6}$

Prav slednjo opredelitev raziskovalnega profila glede na glasbeno zvrst ali slog, ki jo kot posledico globalizacije in »splošnih trendov« na tržišču znanja postavlja v premislek sodobnost, kaže ohraniti v misli ob Bemetzriederjevi socio-estetski razpravi o nacionalnih

Pred nekaj leti je Henkjan Honing z zanosnim naslovom »Povratek sistematične muzikologije: novi empirizem in kognitivna revolucija ('The Comeback of systematic Musicology: new Empiricism and the cognitive Revolution'. V: Tijdschrift voor Muziektheorie, $9(3)$ / 2004, 241-244) povzel prizadevanja, ki so značilna za sodobno muzikologijo: iskanje raziskovalnega aparata, ki bi bil zmožen obravnave ne le recepcije glasbenih struktur, temveč glasbe kot družbenega pojava. Meddisciplinarne zahteve, sicer tako rekoč vpisane v srce muzikologije kot discipline, naj bi bile usmerjene k vzpostavitvi raziskovalnega aparata, ki bi glasbo mogel obravnavati s treh temeljnih gledišč: 1. fizikalističnega ali "paradigmatsko znanstvenega« (glasba kot snovni pojav), 2. imanentnega ali "dekonstruktivističnega ( glasba "per se« kot pojav raziskovalne domene humanističnih in družboslovnih študij) in 3. kognitivnega, po katerem je glasba witself a product of cultural convention and of the facts of embodiment, being instantiated in the cognitions of the members of a culture". (Ian Cross. 'Music \& science: three views'. V: Revue Belge de Musicologie, Vol LII (1998), 207-214.) Kljub nekoliko pretirani dikciji tovrstnega disciplinarnega modeliranja muzikologije, ki skuša v osnovi zajeti tako »tekst k kot »kontekst « glasbe, je mogoče reči, da sta Honingova proklamacija in Crossova delitev pristopov h glasbi značilni, nikakor osamljeni pričevanji o sodobni muzikološki praksi, ki je po »kulturološkem valu« ob koncu osemdesetih zajel še bolj naravoslovno-družboslovni "empirični val«, o katerem priča recimo lansko leto (2006) osnovana revija Empirical Musicology Review, ki je nastala iz podobnih pobud in namenov kot zbornik Eric Clarke / Nicholas Cook \{ur.\}. Empirical Musicology: Aims, Methods, Prospects. New York: Oxford University Press, 2004. Avtorji tega zbornika so obenem tudi organizatorji konference na temo empirične muzikologije.

6 Podobno kot se recimo Mladen Dolar v vrsti drugih raziskovalcev glasbe postavi na stališče razumevanja razlik pri zagovornikih posameznega slogovnega vrednotenja glasbe, ki je vselej vezano na določene družbene danosti ('Function beyond function? Reflections on the functionality of the autonomous'. V: De musica disserenda II/2 [2006]), tudi danes - v imenu znanstvene natančnosti in podrobnega preučevanja - prevladuje mnenje, da se je treba umetnostnih pojavov lotevati »od znotraj«, "V globino«, "lokalizirano«, torej po načelu njihove avtonomije, kakršno sicer prav tako upravičeno terjajo posamezna zgodovinska obdobja, slogi, tokovi, korpusi (notnih) tekstov ipd. na podlagi zdravorazumskega pretresa dostopnih podatkov.

Dejstvo, da raziskovanje ljudskega izročila in popularnih kultur postaja sestavni del vsake uglednejše akademske ustanove, je mogoče razbrati iz okrožnic elektronske pošte muzikoloških »informacijskih posrednikov«, kot sta Euromusicology (www.euromusicology.com ali pa lista Ameriškega združenja za teorijo glasbe (www.societymusictheory.org), kjer je mogoče opaziti povečan muzikološki interes za "glasbe sveta« in različne glasbenopopularne zvrsti kot pomembnega dela kurikularne ponudbe zlasti angleško govorečih kultur. 
glasbah 18. stoletja, ki jo v spisu Glasbena toleranca razgrne uvodna opredelitev »nacionalnih šol« tistega časa v obliki trenj med gluckisti, piccinisti in ljubitelji francoske glasbe:

On dispute beaucoup aujourd'hui sur les schef-d'œuevres en musique; les uns n'accordent du génie \& du goût qu'aux Ouvrages Italiens, les autres donnent la pomme aux Allemands. Les Piccinistes (s'est ansi qu'on nomme un des Partis disputans,) soutiennent qu'il n'y a qu'une bonne Musique, qui est l'Italienne. Tous les Peuples de l'Europe en conviennent selon eux, excepté quelques François de mauvais goût, qui sont enchantés des petits talens de leur Pays. S'ils accordent à la Musique Instrumentale des Allemandes de la force \& de l'effet, ce n'est que pour pouvoir ajouter, mais l'esprit, le génie \& le goût n'existent que dans les compositions Italiennes.

Selon les Gluckistes, (c'est le nom de l'autre Secte) les Italiens ne sçavent que chatouiller l'oreille; ils ne connoissent que [str. 6] quelques formes, agréables à la verité, mais uniformes \& par-là ennuyeuses. Les Allemands sont les vrais Musiciens; ils possedent l'Art, connoissent l'empire des sons; ils tonnent \& commandent aux passions.

Ce ne sont ni les Italiens ni les Allemands qui raissonent ainsi, ils applaudissent, souvent le talent musical François: à la vérité ils n'en sont point enthousiastes; parvenant rarement à donner le bon jour à la Françoise, ils ne peuvent pas sentir tout l'esprit \& toute la délicatesse de notre expression: ce sont des François qui soutiennent dans la Capitale de leur Patrie, que leur Musique n'est pas une Musique: les chef-d'oeuvres de Rameau; de Duni, de Monsigni, de Philidor, de Grétry, de Gossec \& de Floquet sont pour eux de petite Musique. Ils n'écoutent la Poésie Françoise, chantée, qu'autant qu'elle est accentuée, mesurée, phrasée, animée \& embellie par Compositeur Allemand ou
Danes se veliko govori o velikih glasbenih delih; nekateri priznavajo genij \& okus samo italijanskim delom, drugi prisegajo na nemška dela. Piccinisti (tako je ime stranki disputantov) menijo, da je samo ena glasba dobra - italijanska. Vsi Evropejci so prepričani, da je tako, razen nekaterih Francozov s slabim okusom, ki so očarani nad malimi talenti svoje dežele. Če že priznavajo moč in uspeh instrumentalni glasbi Nemcev, to počnejo le zato, da bi lahko pridali: a duha, genialnost in okus imajo samo italijanske kompozicije.

Po Gluckistih (to je ime druge sekte) Italijani zgolj očarajo uho; poznajo le nekaj glasbenih oblik, v resnici prijetnih, a uniformnih in zato dolgočasnih. Nemci so pravi muziki; posedujejo umetnost, poznajo kraljestvo zvoka; silovito izbruhnejo in krotijo čustva.

A ne Italijani ne Nemci niso tisti, ki tako razmišljajo. Oni pogosto aplavdirajo glasbenemu talentu Francozov: v resnici niso pretirano navdušeni; redkokdaj uspejo Francozu voščiti dober dan in ne morejo čutiti vsega duha in vseh posebnosti našega izraza: sami Francozi v prestolnici se odrekajo bogastvu svoje domovine, češ da njihova glasba ni glasba. Najboljša dela, ki so jih napisali Rameau, Duni, Monsigni, Philidor, Grétry, Gossec in Floquet so za njih majhna glasba. Oni ne poslušajo péte francoske poezije, razen kadar jo poudari, prilagodi, frazira, razživi in olepša kak nemški ali italijanski skladatelj. Uspeh, ki so ga imele Gluckove opere v Parizu, je nekatere očaral; sloves g. Piccinija je ustvaril stranko drugih: ugovarjanje, kritika in zavist ter samovšečnost so utrdili obe stranki: aplavz jih je navdušil, navdušenje pa je večino zaslepilo. Tako eni kot drugi so 
Italien. Le success qu'ont les Opéra de M. Gluck à Paris, séduit les uns; la renommée de M. Piccini a formé le Parti des autres: les objections, la critique, la jalousie \& l'amour-propre ont fortifié les deux Partis: les applaudissemens les ont enthousiasmé, \& l'enthousiasme a aveuglé la plupart: tous sont [7] injustes envers les Musiciens de leur Pays: s'ils prononcent par fois les noms de quelques-uns de nos Célèbres, ce n'est que pour les attacher au char de Gluck, ou à celui de Piccini.

Qu'un troisieme Parti en faveur des Compositeurs François, auroit beau jeu avec ces Détracteurs du talent national; leurs prétentions exclusives ne tiendroient pas long-temps contre la force des raisons qu'on pourroit leur opposer. Il ne seroit pas triste, ce Parti: on pourroit égayer la discussion, car la plupart des Docteurs disputans sont un peu incertains de leur goût $\&$ de leur connoisance musicale: ils ont change d'Idole très-souvent, tour-à-tour ils ont encensé Lully, Rameau, Mondonville, Duni, Philidor, Monsigni, Grétry, Gossec, Floquet; \& par une singularité bizarre, on trouve ajourd'hui parmi les partisans de la Musique Italienne, ceux qui ont l'ouie un peu dure; \& ceux qui ont la reputation d'avoir les organs delicates, sont mêlés parmi les Amateurs de la Musique Allemande ... J'aimerois assez à rompre une lance pour ces idoles delaissées \& offensées: mais on se donne un ridicule à Paris, en parlant du mérite des François; les Allemands, les Anglois \& les Italiens sont les Héros par excellence; d'ailleurs, je suis Toutiste, je n'ose blâmer personne, je jouis des trios Musiques; l'expression Allemande m'est pres-qu'aussi familiere que l'expression Françoise, \& la Musique Italienne charme infiniment mon Oreille, quoiqu'elle présente à mon esprit des images différentes de celles que m'annoncent le geste, la phy- krivični do glasbenikov svoje domovine: če že izustijo ime kakega naših znamenitih glasbenikov, jih priključijo bodisi Gluckovemu bodisi Piccinijevemu vozu.

Najsi je tretja stranka, ki zagovarja francoske skladatelje, še tako zmožna zlahka opraviti s temi, ki blatijo narodni talent, njihove izključujoče namere ne bodo dolgo vzdržale nasproti moči razuma, s katerim bi jim lahko nasprotovali. Ta stranka ne bi smela biti žalostna: poživiti bi bila morala diskusijo, saj večina doktorjev disputantov ni prepričana v svoj okus in svoje glasbeno znanje - idole spreminjajo zelo pogosto in hvale pojejo vsem po vrsti, Lullyju, Rameauju, Mondonvilleu, Duniju, Philidorju, Monsigniju, Grétryju, Gossecu, Floquetu; in prav nenavadno je, da najdemo med pristaši italijanske glasbe take, ki imajo slab sluh; med amaterje nemške glasbe so pomešani tisti, ki slovijo po svojih občutljivih organih ... Zelo rad bi se zavzel za njihove zapuščene in razžaljene idole, a človek se v Parizu osmeši, ko govori o zaslugah Francozov. Nemci, Angleži in Italijani so heroji brez primere. Še več, tudi sam sem tutist in nikogar ne upam kriviti - uživam v vseh treh glasbah; nemški izraz mi je skoraj enako domač kot francoski, italijanska glasba pa moje uho neskončno očara, dasi mojemu duhu prikaže drugačne podobe od tistih, ki mi jih vzbujajo kretnja, fizionomija in besede italijanskega jezika; oskrbi mi čudovite trenutke, čeprav se moji občutki ponavadi zelo razlikujejo od tistih, ki navdajajo ljudi, vajene italijanskega jezika, manire in izraznosti.

Če mi ta dvojni razlog veže roki in mi preprečuje stopiti v diskusijo, da bi zagovarjal in maščeval slavne umetnike, katerih velike mojstrovine občudujem, bi želel vsaj zmanjšati število njihovih sovražnikov in razkriti šibkost tistih, ki jih ne bi mogel spreobrniti. Morda se bodo v Londonu, na 
sionomie \& les paroles de l'Italien; elle me procure des momens délicieux, quoique mes sensations soient, pour l'ordinaire, trés-opposées à celles que paroissent en recevoir les gens habitués à la langue, à la maniere \& à l'expression Italienne.

Si cette double raison m'arrête \& m'empêche d'entrer en lice, pour defendre \& pour venger les Artistes célèbres, don't j'admire les chef-d'outres, je veux du moins chercher à diminuer le nombre de leurs ennemis, \& découvrir la foiblesse de ceux que je ne pourrois pas convertir; il naîtra peut-être un jour à Londres, à Vienne, ou à Rome, quelques Renégats qui, jaloux ou ennuyés du mérite de leurs voisins, chanteront les éloges des Fraçois.
Dunaju ali v Rimu kdaj rodili kaki izdajalci, ki bodo - zavistni ali naveličani zaslug svojih sosedov - peli hvalo Francozom.

Četudi je širitev Evropske Unije ob koncu 20. stoletja - iz različnih razlogov, z različno intenziteto in ukrepi - poživil vprašanja o nacionalnem, te muzikološke »življenjske tematike«(C. Kaden) danes nikakor ne kaže razmejevati od drugih prizadevanj po osvetljevanju identitet. Spremljajo namreč tako popularnost "glasb sveta«, kot regionalnih, lokalnih, alternativnih, obrobnih ali kakor koli drugače s strani »akademske muzikologije» domnevno v ozadje potisnjenih glasb. Ne nazadnje se ena vseprisotnih idej sodobnosti - da je treba upoštevati druge in drugačne, skratka vse glasbe - kot osrednji pokazatelj razsvetljenske drže sodobne etno/muzikologije ${ }^{8}$ izteka v niz vprašanj o (ne le nacionalni) identiteti pojavov. Primerjati ga mogoče z okroglo mizo, kjer sta glavna sogovornika na eni strani teoretska in filozofska odprtost, medtem ko na drugi strani sedi domala empirično dokazljiv pragmatizem, vezan zlasti na geografske, politične in jezikovne danosti. Skratka, vanj sodi domala vse in opredelitve identitete terjajo meddisciplinarnost.

Seveda drži, da je strokovna analiza "vseh reči, povezanih z glasbo« sestavni del tudi programskega orisa muzikologije Guida Adlerja (Umfang und Ziele der Musikwissenschaft) - teoretskega mejnika nemške muzikologije, za katerega se zdi, da je praktično zadihal s polnimi pljuči predvsem v interdisciplinarnih prizadevanjih, ki jih danes izrazito narekuje pragmatizem, domnevno značilen za anglosaško raziskovalno tradicijo. Toda drži tudi, da so navezovanja (recimo nacionalne) identitete na konkretne pojave vselej razpeta med določene substance, kakršna je recimo naravni jezik, in izmuzljive specifike, kot so relacije, konteksti, okoliščine ipd., odpirajoč na stežaj vrata »tutističnim« (= holističnim) metodološkim raziskavam. Naj navedem primer iz slovenske glasbene kulture. Če bi recimo trdili, da glasba Primoža Ramovša ne odraža nacionalne biti, ker so ljudske prvine, v kolikor v njej obstajajo, dodobra prekrite, bi prišli v zagato pri iskanju ugovora na prepričanje, ki ga je na žalni seji ob Ramovševi smrti 13.1.1999 podal

8 Odmevna raziskovalca, kot sta Christian Kaden in Nicholas Cook, sta sijajna primera udejanjanja načela »razsvetljenskega duha" v muzikologiji. Prim. Christian Kaden. Des Lebens Wilder Kreis. Musik im Zivilisationsprozeß3. Kassel: Bärenreiter, 1993, zlasti 171-227. - Nicholas Cook, Analysing Musical Multimedia. Oxford: Oxford University Press, 2000. 
akademik Lojze Lebič rekoč: „Prepričan sem, da bomo v prihodnje v Ramovševi muziki odkrivali veliko več naše slovenske duhovne antropologije kot se nam danes zdi.«9 Dejstvo je, da tudi Ramovševa glasba tvori del slovenske glasbene identitete - a je prav tako treba šteti za dejstvo to, da opredelitev Ramovševe slovenskosti potrebuje analitični aparat, ki je sposoben razlikovanja različnih, glasbenih v enaki meri kot ne-glasbenih pla(s)ti slovenskosti.

Zavajajoče se zdi torej iskati izključujoče alternative tipa ali/ali - zavajajoče je vprašati, ali so identitete zgolj kulturološka konstrukcija ali pa je, denimo, jezikovna podstat jedro nacionalne identitete. Iskati je mogoče kvečjemu odgovore na domneve, ki govorijo v prid eni ali drugi poziciji, ne da bi katero od obeh smeli odmisliti. Toda kako opredeliti naslednje stališče Bemetzriederja, ki »substanco nacionalnega« veže na jezik, a ne na intonanco, temveč na »vzvišena čudesa poezije» (»sublimes merveilles de la Poésie»)?

Le Génie impartial inspire les Habitans [9] de Paris aussi-bien que ceux de Naples \& de Vienne; le bon gout qui seul sçait distinguer les belles situations \& beaux momens du monde physique \& moral; cette rare \& précieuse qualité de l'intelligence humaine appartient à tous les hommes. Les Italiens, les Allemands 'les François ont produit \& produisent encore tous les jours des chef-d'oeuvres de Musique du meilleur goût: je crois même que toute Nation qui aura éléve sa langue aux sublimes merveilles de la Poésie, pourra un jour avoir sa Musique propre.
Nepristranski genij navdihuje prebivalce Pariza enako kot tiste Neaplja in Dunaja; dober okus, ki zna edini razločiti med lepimi situacijami in lepimi trenutki fizičnega in duševnega sveta - ta redka in neprecenljiva kakovost človekove inteligence - pripada vsem. Italijani, Nemci in Francozi so ustvarjali in še vedno iz dneva $\mathrm{v}$ dan ustvarjajo velike glasbene umetnine najboljšega okusa: verjamem celo, da bo vsak narod, ki bo svoj jezik povzdignil do vzvišenih čudes poezije, nekega dne lahko imel svojo glasbo.

Zastavljeno vprašanje terja dva niza odgovorov na temeljna spoznavoslovna, v enaki meri metodološko kot vsebinsko občutljiva vprašanja o razmerju med substančnim in relacijskim »jedrom «(ne le nacionalne) identitete. V konkretnem primeru je oba niza vprašanj mogoče formulirati takole: ali Bemetzrieder napeljuje misel k vprašanju vzvišenega učinka jezika, ki naj ga glasba posnema, ali meri na jezikovno strukturiranost, ki naj bo ukrojena po strukturah in mehanizmih jezika kot veliko širše razumljenega komunikacijskega sredstva - če parafraziram Bemetzriederjeve besede o okusu s teorijo »multiple intelligencies« Howarda Gardnerja: kot »neprecenljive kakovosti človekovih inteligenc«?

Kar zadeva odgovor na postavljeno vprašanje o nacionalni prevladi se Bemetzriederjev spis na tej točki pravzaprav konča: slidi argumentacija, ki osvetljuje ozadje odgovora. ${ }^{10}$ Avtor namreč nadalje skuša znanstveno utemeljiti nacionalno identiteto v glasbi prek

9 Lojze Lebič. 'Primož Ramovš'. Rokopis 1999, 3. (Hrani Lojze Lebič.)

10 Vprašanje je ne nazadnje treba umestiti med vrsto zgodovinskih in teoretskih poglavij o vzporednicah med jezikom in glasbo, ki ob koncu 18. stoletja izgubijo teoretsko trdnejšo vez z baročnim naukom o glasbenoretoričnih figurah in poleg strukturnih vzporednic s pesniškimi stopicami šele v 20. stoletju pridobijo trdnejši teoretski okvir zlasti v idejah govorjenega petja ("Sprechgesang« A. Schönberga) in glasbene intonacije (L. Janaček, B. Asafjev, D. Schnebel idr.), ki je z navedenimi točkami še zdaleč ni mogoče označiti za sklenjen tematski krog. Gre za za tematiko umevanja glasbe kot komunikacijskega pojava tako na nevrofiziološki kot antropološki in kulturološki, kar odpira od nekdaj privlačne muzikološka vprašanja v vedno drugačni luči. 
treh med seboj povezanih argumentacijskih linij: prek bio-fiziološke analogije govorjenega jezika in glasbe nadaljuje v duhu izmuzljivih pojmov-smerokazev estetike okusa, ki bi danes sodili k osebnostni psihologiji, s kulturološkim portretom glasbene prakse, izhajajoč iz primerjave treh »nacionalnih korifej«, Monsignija, Glucka in Piccinija. Avtor se očitno zavedajoč težav loti svojega znanstvenega izvajanja s pomenljivo etično cezuro, ki bi jo pri obravnavi začrtane vsebine mogli brez predsodkov podpisati tudi danes:

Ce n'est peut-être pas le moment d'annoncer ce Tolérantisme Musical; l'expérience n'a pas encore assez instruit; les meilleures preuves ne parồtront pas évidentes. Les pretensions exclusives font fortune plus aisément; elles donnent un air savant à celui qui les soutient; ceux qui sont les Héros, les adoptent aveuglément, \& la jalousie des offensés favorise leurs progress. Il n'est pas de même d'une opinion tolérante; son indulgence lui donne un air timide \& incertain, ne décidant pas pour un contre tous, elle flatte peu \& n'irrite personne: une telle opinion n'est pas piquante, on ne peut pas la dire avec [10] enthousiasme; il faut l'appuyer de fortes raisons pour la faire passer, \& puis les raisons exigent l'examen qui est toujours difficile \& souvent fort ennuyeux. Vaincons les difficultés; sondant l'opinion qui nous paroît la plus raisonnable, nous avancerons peut-être l'époque de la Musique, \& nous aurons favorisé le plus innocent des plaisirs.
Nemara ni pravi trenutek za razglasitev glasbene tolerance; izkušnja nas še ni dovolj izučila; najbolj očitni dokazi se ne bodo zdeli dovolj jasni. Izključujoče namere zlahka dajejo večji izkupiček; tistega, ki jih podpira, navdajajo z videzom učenosti; heroji jih slepo sprejemajo in zavist užaljenih napihuje njih napredek. S strpnim stališčem pa ni tako. Njegova prizanesljivost mu daje plašen in dvomeč videz; ker se ne odloči ne za ne proti, malo laska in nikogar ne vznemirja: takšno stališče ni bodičasto in ne moremo ga izreči z zanosom; da bi ga sprejeli, ga je potrebno podpreti z močnimi razlogi, razlogi pa zahtevajo premislek, ki je vedno težaven, pogosto je tudi zelo dolgočasen. Premagajmo težave; če bomo sprejeli stališče, ki se nam zdi najbolj smiselno, bomo morda pomagali napredku svoje glasbene dobe in podprli najbolj nedolžnega vseh užitkov.

»Najbolj nedolžnega vseh užitkov« podpirajo prejkone vsi, a razlage, zakaj, niso enake in ne dobljene na enak način. Zavedajoč se krhkosti celotnega poteka argumentacije, Bemetzrieder na tem mestu začrta dolg lok izvajanja jedra nacionalne glasbe in njenega družbenega položaja. Izvajanje je mogoče deliti na tri med seboj povezane sklopa tematik, ki bi jih mogli označiti kot nevro- ali biofiziološko in kulturološko opredelitev nacionalnega z veznim odlomkom (v naslednjem delu citiranega besedila pod lomljeno črt), ki bi ga danes umestili v domeno psihologije osebnosti. ${ }^{11}$

11 Če je mogoče biofiziološke vzporednice z Bemetzriederjevim spisom iskati na različnih koncih po naraščajočem korpusu obravnav, ki se sklicujejo na „biomuzikologijo«, in bi za sodobne kulturološke poglede na glasbo mogli napotiti k razičnim glasbenosociološkim, antropološkim in kulturološkim obravnavam, kaže s področja psihologije osebnosti in glasbe med najbolj temeljitimi študijami opozoriti na: Peter J. Rentfrow / Samuel D. Gosling. »The Do Re Mi's of Everyday Life: The Structure and Personality Correlates of Music Preferences «Journal of Personality and Social Psychology 84/6 (June 2003): 1236-1256. 
V prvi del argumentacije sodi vez med glasbo in strukturami govorjenega jezika; ob tezi, da se je glasba razvila iz "naravnega petja» in so jo geografske in biološke razlike med ljudmi diferencirale, je glavni sklep tega dela ta, da ni univerzalne glasbe, ki bi bila »lastna vsem podnebnim razmeram, vsem ljudem in vsem jezikom«:

Le chant est le signe naturel de nos plaisirs, mais l'homme civilisé est loin de la nature; les chef d'ouvres du langage ont multiplié \& varié nos sensations à l'infini. Il ne faut pas moins qu'une savante harmonie, unie à une parfaite mélodie, pour les exprimer toutes; le geste, la physionomie \& la parole ne sont pas de trop, si on veut les manifester \& les communiquer aux Auditeurs. Les Italiens sont le premier Peuple de l'Europe moderne, qui ait substitute une Musique au chant naturel; leur langage \& leur Musique ont cheminé d'un pas égal vers la perfection. Le même accent, la même prosodie, le même rythme \& même esprit règnent dans leur langue \& dans leur Musique, l'instrumentale est aussi Italienne que la vocale, on ne fait pas trop si leur maniere de chanter est tirée de leur maniere de parler, ou si leur maniere de parler est tirée de leur maniere de chanter. Une langue sonore [11] \& chantante, une Musique délicieuse où l'harmonie est sagement combinée avec la mélodie, voilà ce qui distingue aujourd'hui les Italiens de tous les Peuples de la terre. Mais cette langue agreeable, cette Musique divine, peuvent-elles servir de modeles à toutes les Nations? Cela paroît être l'opinion générale, du moins quant à la Musique, car on chante ajourd'hui par-tout la langue Italienne: Pour moi, je ne peux pas penser de même; je crois ne choquer personne, en le disant tout haut; je ne suis pas le premier ni l'unique de mon opinion. Le Spectateur Anglois (Discours XIII) a dit, il y a long-temps ... "Je remarquerai que l'accent de chaque Nation lui est si particulier, que'il differe de celui de toutes les autres, comme on peut le voir par les Gallois \& par les Ecos-
Petje je naravni znak naših užitkov, a civilizirani človek je daleč od narave; jezikovne mojstrovine so naša občutja pomnogoterile in popestrile $\mathrm{v}$ neskončnost. Za njihov izraz je potrebna vešča harmonija, združena s popolno melodijo; gesta, poteze in beseda niso odveč, če jih kdo želi izraziti in posredovati poslušalcem. Italijani so prvo ljudstvo moderne Evrope, ki je naravno petje zamenjalo z glasbo; njihov jezik in njihova glasba sta $\mathrm{k}$ dovršenosti hodili z enakimi koraki. Isti poudarek, ista prozodija, isti ritem in isti duh prežemajo njihov jezik in njihovo glasbo, instrumentalna glasba je enako italijanska kot vokalna, in ni pretirano reči, da je njihov način petja izpeljan iz njihovega načina govora. Zveneč in pojoč jezik ter prefinjena glasba, kjer se harmonija in melodija modro prepletata, Italijane danes razločujeta od vseh ljudi na svetu. Toda: ali lahko ta prijeten jezik, to božansko muziko, rabimo za model vseh nacij? To bi utegnilo biti splošno mnenje, vsaj kar zadeva glasbo, saj se danes povsod poje italijansko: sam ne mislim enako, verjamem, da ne bom koga šokiral, če to povem na glas - pri tem nisem ne prvi ne edini. Angleški opazovalec (Discours XIII) je že dolgo tega dejal: »opazil bom, kako se akcenti vsake nacije tako lastni njim, da se po njih razlikujejo od vseh ostalih, kot je mogoče opaziti pri Valižanih in Škotih, četudi so nam tako blizu. Po drugi plati pa pri tem ni mišljena izgovorjava vsake posamezne besede, temveč zven celotnega govora. Odtod ponavadi pritožbe Angleža, ki sliši izvajati tragedijo v francoščini: da vsi igralci izgovarjajo na istem tonu; in 
sois, quoiqu'ils soient si près de nous. D'un autre côté, l'accent don't il s'agit, n'est pas la prononciation de chaque mot à part, mais le son de tout le discours. De-là vient qu'il est si ordinaire à un Anglois qui entend jouer une Tragédie en François, de se plaindre que tous les Acteurs prononcent sur le même ton; c'est pour cela qu'il préfere sagment ses [12] compatriotes, sans penser qu'un François, ou étranger, se plaint aussi de la monotonie des Acteurs Anglois" ... Plus bas, parlant des Opéra Italiens, executes à Londres; il ajoute ... "Les marques d'interrogation ou d'admiration dans la Musique Italienne, ont quelques rapports avec les tons naturels d'une voix Angloise, quand nous sommes en colere; jusques-là que j'ai vu souvent nos Auditeurs fort trompés à l'égard de ce qui se passoit sur le théatre, \& s'attendre à voir le Héros casser la tête à son domestique, lorsqu'il lui faisot une simple question, ou s'imaginer qu'il se querelloit avec son ami, lorsqu'il lui souhaitoit le bonjour" ... Depuis deux ans, des Littérateurs François ont savamment raisonné, pour prouver que les Opéra Italiens sont déplacés sur notre théatre, \& que la Musique Italienne ne convient nullement à notre Poésie: il est vrai, ils n'ont dit cela que pour mettre en place un autre modele universel, la Musique forte \& expressive d'un célèbre Compositeur Allemand; par conséquent, cette derniere autorité n'est qu'une demipreuve en faveur de mon opinion. Le Savant Court de Gebelin me fournit des preuves [13] plus solides dans la profonde Histoire naturelle de le parole; cet Auteur célebre remonte à origine de tout langage, tire la diversité des langues des organs mêmes de la voix; son exposé du monde primitif est contraire à toute universalité. Selon lui, l'homme sortant des mains de la nature n'a pas un égal penchant pour tous les sons de la voix, ni pour toutes les prononciations; l'air, le climat, les productions du lieu de sa zato ima modro raje svoje sonarodnjake [12], pri tem pa ne pomisli, da tudi Fran$\mathrm{COZ}$ ali tujec negoduje nad monotonijo angleških igralcev« ... Kasneje, govoreč o italijanski operi, izvedeni v Londonu, doda: »Preizpraševanja in občudovanje v italijanski glasbi imata nekaj skupnega s tonom angleškega glasu, ko smo jezni; tako sem pogosto videl naše poslušalce krepko zavedene o tem, kaj se dogaja na odru, pričakujoč, da bo heroj razbil glavo služabniku, ko mu je ta postavil preprosto vprašanje, če se krega s svojim prijateljem, ko mu je slednji voščil dober dan« ... Že dve leti francoski literati učeno razmišljajo, kako bi dokazali, da italijanska opera ni za naša gledališča in da italijanska glasba sploh ne ustreza naši poeziji. Res je, da so to rekli le, da bi postavili še en univerzalni model, krepko in izrazno glasbo nekega slavnega nemškega skladatelja; posledično je ta zadnja avtoriteta le polovični dokaz vprid mojemu stališču. Učenjak Court iz Gebelina mi ponuja bolj čvrste dokaze v poglobljeni Naravni zgodovini govora; ta slavni avtor seže nazaj k izvoru vseh jezikov, raznolikost jezikov izpeljuje iz samih organov glasu; njegov prikaz primitivnega sveta povsem nasprotuje vsaki univerzalnosti. Pravi, da človek, ki ga je ustvarila narava, nima enakega nagnjenja do vseh zvokov glasu, niti do vsakršne izgovorjave; zrak, klima, dobrine rojstnega kraja, njegove potrebe in izoblikovanost njegovih organov neprestano vplivajo na njegov genij in omejujejo njegov specifični okus ... Zatorej se mora glasba med različnimi ljudstvi razlikovati; tako kot govor.

Govoreč o načinih ali manirah govora, Gebelin pravi: »V regijah, kjer je podnebje skrajno vroče in kjer se kri vročično pretaka, se mišice pevskega glasbila bolje širijo in so bolj igrive: usta se tako laže odpirajo, z večjo močjo pritiskajo na no- 
naissance, ses besoins \& la conformation de ses organs influent sans cesse sur son génie, \&bornent son goût particulier ... La Musique doit donc varier chez les différents Peuples; ainsi que le discours.

Parlant des modes ou des maniéres de Gebelin dit ... "Dans les contrées où l'air est brûlant \& où le sang coule avec impétuosité, les fibres de l'instrument vocal se dilatent davantage \& ont plus de jeu: la bouche s'ouvre donc plus facilement, elle fait plus d'effort sur l'extrémité intérieure; on aspire donc. Dans les contrées où le froid est rigoureux, où tout mouvement est ralenti, où toutes les fibres sont resserrées, la bouche s'ouvre beaucoup moins; on prononce du devant de la bouche, on siffle plutôt au'on ne parle. [14] Dans les montagnes où poumons sont plus exercés que dans les plaines, la prononciation est beaucoup plus rapide. Ceux qui vivent dans l'abondance \& dont les moeurs sont douces \& aisées, ont une prononciation douce \& amolie; ils fuient les sons âpres \& fortement prononcés des peuples plus grossiers.

Chez un même peuple, la prononciation change avec les moeurs: nous ne pourrions soutenir celle de nos peres du quinzième siécle, elle nous paroîtroit infiniment trop rude ... La prononciation de la langue Françoise s'adoucit singuliérement vers la fin du sixieme [!] siecle; les mots en $A$ se changerent en $E$, \& la plupart de ceux où $o i$ se prononçoient aussi fortement que dans Suédois, se prononcerent en $E$, ensorte que le nom des François n'eût plus le même son que le nom du Roi François ... C'est ainsi qu'une partie des Grecs changerent de prononciation à mesure qu'ils se civiliserent; \& qe les Ioniens Eles Athéniens prononcerent en $E$, les mots que les Doriens montagnards $\&$ agrestes continurent de prononcer en $A$ " ... Parlant des sons les plus simples, des sept sons fondamentaux de l'octave, M. Court de Gebelin dit que le plus haut se prononce par tranjost; ljudje torej vdihavajo. V regijah, kjer vladata mraz in težke okoliščine, kjer se gibi upočasnijo, kjer so vsa mišična vlakna bolj skrčena, se usta odpirajo veliko manj; izgovarja se s sprednjim delom ust, prej žvižgajoč kot govoreč. V gorah, kjer so pljuča bolj razvita kot na ravninah, je izgovorjava veliko hitrejša. Tisti, ki žive v izobilju in katerih nrav je mehka ter mila, imajo tudi mehko in prožno izgovorjavo; bežijo pred rezkimi in glasnimi glasovi bolj robatih ljudi.

Pri istem ljudstvu se izgovorjava spreminja z navadami: ne bi mogli prenašati izgovorjave naših očetov iz petnajstega stoletja, ki bi se nam zdela skrajno groba ... Izgovorjava francoskega jezika se proti koncu šestega stoletja nenavadno omehča; besede na A se spremenijo v E in večina besed, kjer se 'oi' [izg. 'ua', op. prev.] močno naglašuje, kot pri besedi Suédois [Šved, op. prev.], se izgovarja kot E, tako da ime François [Francoz, op. prev.] nima več enakega zvena razen pri imenu Roi François [kralj Franc, op. prev.]...Tako je del Grkov $\mathrm{v}$ procesu civiliziranja spremenil izgovorjavo; Ionci in Atenci so z E izgovarjali besede, ki so jih dorski gorjanci in kmetje še naprej izgovarjali z A «... Razpravljajoč o najpreprostejših, sedmih osnovnih zvokih oktave, gospod Court de Gebelin meni, da so usta pri izgovorjavi najvišjih zvokov najbolj odprta; najbolj pa zaprta pri izgovorjavi najnižjih tonov: prvi pojav ponazori s črko A, drugega s črkama OU [izg. 'u', op. prev.]; po njegovem pet vmesnih zvokov ustreza našemu skrajno odprtemu E, našemu navadnemu E, ki se izgovarja $\mathrm{V}$ sredini ustne votline, ter našim I, O in U; in $\mathrm{v}$ resnici se črke A, È, E, I, O, U, OU ne morejo izgovoriti s raztegovanjem ust, ki se vedno bolj zapirajo. Avtor primitivnega sveta dodaja, da ima teh sedem zvokov (sedem duhov preteklosti) lastnost, da se 
la plus [15] grande ouverture possible de la bouche; \& que la plus bas se prononce par la plus petite ouverture possible: il désigne le premier par la lettre $A$ \& l'autre par les lettres $O U$; selon lui les cinq sons intermédiaires repondent à notre $E$ extrêmement ouvert, à notre $E$ ordinaire prononcé du milieu de la bouche, à l'i, à l'o, \& à l'u; en effet les lettres A, È, E, I, O, U, OU, ne peuvent se prononcer que par l'allongement de la bouche, qui se ferme de plus en plus. L'Auteur du monde primitif ajoute que ces sept sons, (les sept esprits des anciens) ont la propriété de se prononcer de diverses maniéres: 1 . Avec beaucoup de douceur, du milieu de la bouche. 2. Du fond du gosier en aspirant avec force. 3. En les terminant par un leger son nazal. 4. en les prononçant lentement. 5. en les prononçant briévement

Ces Observations ne favorisent pas l'opinion d'une Musique universelle \& propre à tous les climates, à tous les peuples \& à toutes les langues; elles ne favorisent pas non-plus l'opinion de ceux qui croient que la Musique est une langue naturelle: qu'ils accordent ce titre à la Musique Allemande, à la Musique Françoise, à la Musique Italienne ou à la Musique Iroquoise, l'homme [16] du monde primitif ne sera pas de leur avis; parcourant toute la terre, il pourroit bien ne pas rencontrer un seul air de son goût: je m'imagine qu'il auroit beau faire, dresser les oreilles, ouvrir la bouche \& agrandir les yeux, il ne comprendroit pas grand'chose ni au discours, ni à la Musique des Italiens malgréle jeu des gestes \& de la physionomie: je ne pense pas qu'il puisse trouver là les signes de ses sensations ou les images de ses idées, tous deux à coup sûr aussi pauvres \& aussi bornés que son chant \& son language; je ne fais ce qui pourroit se passer dans son ame, mais il me semble le voir fort embarrassé \& presqu'aussi étourdi que le feroit un oiseau libre qui ne fait lahko izgovorijo na različne načine: 1 . z veliko mehkobe, v sredini ustne votline, 2. z grleno izgovorjavo, pri močnem vdihu, 3. tako da jih končamo z lahnim nazalnim zvokom, 4. s počasno izgovorjavo, 5. s pohitevanjem pri izgovorjavi.

Ta opažanja ne govorijo v prid univerzalni glasbi, ki bi bila lastna vsem podnebnim razmeram, vsem ljudem in vsem jezikom; ne podpirajo mnenja tistih, ki verjamejo, da je glasba univerzalen jezik: ki ta pridevek podeljujejo nemški glasbi, francoski glasbi, italijanski glasbi ali pa irokeški glasb - človek primitivnega sveta se ne bi strinjal z njihovim stališčem; dasi bi prehodil ves svet, morda ne bi našel ene samcate pesmi po svojem okusu: kar predstavljam si, da četudi bi dobro našpičil ušesa, odprl usta in razširil oči, kljub temu ne bi razumel kaj dosti jezika, niti same glasbe Italijanov, igri gest in telesa navkljub. Ne mislim, da bi mogel najti znamenja svojih občutkov ali podobe svojih idej, ki so nedvomno tako skromni in omejeni, kot njegove pesmi in njegov jezik. Ne vem, kaj bi se lahko dogajalo v njegovi duši, a zdi se mi, da bi ga stvar močno spravila v zadrego in domala v osuplost - kot svobodno ptico, ki proizvaja svoje naravno žvrgolenje in ki bi po naključju naletela na umetno vzgojene kanarčke. Nadalje na poti bi se naš popotnik z vsakim korakom znašel v večji zadregi; povsod bi slišal razglašeno govorico s petjem, kajti mislim, da mu v Parizu ne bi izvajali francoske glasbe, na Dunaju je največ, na kar bi lahko naletel, nemška glasba prilagojena italijanskim besedam, medtem ko smo se v Londonu odpovedali angleški glasbi že pred tridesetimi leti ... Verjamem, da bi obisk prestolnic $v$ njem pustil vtis razvoja glasbe, ki se pomika v obratnem sorazmerju: najbrž bi se želel ustaliti pri 
que son ramage naturel, \& qui rencontreroit par hasard une petite société de serins élevés à la serinette. Continuant sa route, l'embarras de notre voyageur pourroit bien augmenter à chaque pas; par-tout il entendroit un parler discordant avec le chanter, car je ne pense pas qu'on lui donneroità Paris de la Musique Françoise; à Vienne il auroit tout au plus de la Musique allemande ajustée sur des paroles Italiennes, \& à Londres on a abandonné la Musique Angloise depuis trente ans ... Je crois que son séjour dans les Capitales [17] seroit toujours en raison inverse des progrès de la Musique: c'est chez les peuples dont la musique est encore dans l'enfance qu'il doit vouloir se fixer; c'est là qu'il pourroit un peu s'y reconnoître, leur chant simple encore d'accord avec le langage est près de la nature \& par conséquent à la portée de l'homme du monde primitif.

Le fait n'est pas moins contraire à ces prétensions d'une Musique naturelle, d'une Musique universelle, nulle n'est bonne pour tout le monde; il n'existe aucune universalité de langage, le geste même \& la physionomie distinguent les différens peuples de la terre: l'observateur ne se trompe guerès; l'attitude le maintien \& la mine lui suffisent pour reconnoître la plupart des nations: Partout la voix, le chant \& la Musique ont un goût de terroir ainsi que la parole \& le discours; tout people à son mode ou sa maniére de chanter en tout confirme à sa maniére de parler; chacun a une tournure, une construction propre dans ses compositions: une prononciation particuliére caracterisé jusqu'aux moindres contrées de chaque nation. Si le parler varie en France d'une province à l'autre, le chanter n'est pas le même d'une extrémité à l'autre: je ne sais si le [18] Breton reconnoîtroit son air en Provence, mais à coup sûr le Béarnois ne trouveroit pas sa çhanson en Picardie ... La Musique Françoise chantée par un Italien ne perd pas moins que les vers de Racine ljudeh, kjer je glasba še v povojih; tam bi se lahko nekoliko prepoznal, preprosto petje teh ljudi je še $v$ skladu z govorico in blizu naravi, in je posledično dojemljivo človeku primitivnega sveta.

To dejstvo ni nič manj $\mathrm{v}$ nasprotju $\mathrm{s}$ pretenzijami po naravni glasbi, po univerzalni glasbi, nobena ni dobra za ves svet; ne obstaja kak univerzalni jezik; ne obstaja univerzalnost jezika; celo gesta in fizionomija ločujeta med sabo različna ljudstva sveta. Opazovalec se ne zmoti; drže, ki jih imajo, njihovi izrazi in videz mu zadoščajo, da prepozna večino nacij. Povsod glas, pesem in glasba izražajo maniro ozemlja, prav tako beseda in govor. Vsako ljudstvo ima svoj način petja, ki je povsem v skladu z njihovim načinom govora; za vsak narod je značilno lastno fraziranje, lastna sestava kompozicij: vse do zadnjega okraja, vsako nacijo zaznamuje značilna izgovorjava. Če govor $v$ Franciji variira med posameznimi provincami, petje tudi ni enako: ne vem, ali Bretonec prepozna svojo pesem $\mathrm{v}$ Provansi, a Bearnjan svoje pesmi gotovo ne bi našel v Pikardiji ... Francoska glasba, ki jo poje Italijan, ne izgubi nič manj kot Racinov verz, deklamiran v nemščini ... Avtor v glasbi prepozna svojo domovino z enako lahkoto kot Nemec, ki piše francosko; navade prve vzgoje se težko opustijo - treba je vložiti veliko truda in vrsto let, in potreben je poseben genij, da bi se naturalizirali v tujem izrazu. Italijan prepozna nemške in francoske skladatelje, četudi pojejo pesmi Metastazija: danes je mogoče v Parizu primerjati manire, značilne za tri glavne glasbe Evrope; gospodje Monsigni, Gluck in Piccini nam lahko služijo za primere pri isti gledališki igri. Golkondska kraljica prvega je povsem po francoski modi; naš jezik je tu pét $s$ čistostjo in plemenitostjo; instrumentalna glasba in plesne viže vzbujajo prijetno 
déclames par un Allemand ... L'Auteur en Musique décele sa patrie aussi aisément que l'Allemand qui écrit le François; on perd difficilement l'habitude de la premiere éducation; il faut un grand travail, de longues années \& un don particulier du génie pour nous naturaliser dans une expression étrangére: l'Italien reconnoît les Compositeurs Allemands \& François, quand mêm e ils chantent les Poëmes de Metastaze: on peut ajourd'hui comparer à Paris les meniéres de faire qui caractérisent les trois principales Musiques de l'Europe; MM Monsigni, Gluck E Piccini nous donnent des exemples sur le même Théâtre; la Reine du Golconde du premier est entiérement du mode françois: notre langue y est chantée avec pureté \& avec noblesse; la Musique insrumentale \& les airs de danse inspirent l'aimable gaité qui caractérise notre nation; cet Opéra est ancien, il a déja eu un grand succès il y a douze ans \& il charme encore tous ceux qui oublient pour un moment [19] qu'il faut ajourd'hui être ou Gluckiste ou Picciniste. veselost, ki je tako značilna za našo nacijo; opera je stara in je imela velik uspeh že pred dvanajstimi leti in še vedno očara vse tiste, ki za trenutek pozabijo, da je treba danes biti bodisi gluckist ali piccinist.

Bemetzriederjeva analogija biofizioloških prvin govorjenega jezika in glasbe, ki jo nevrofiziološke raziskave zadnjega desetletja podpirajo nakazujoč njeno univerzalno veljavo, ${ }^{12}$ sodi k temeljnim teoretskim vprašanjem umetnosti, ne le glasbe (čeprav ima v zgodovini glasbe izrazito vlogo). Tematsko sodi k vprašanjem o glasbenih univerzalijah, ki se (po skoraj stoletju) vedno pogosteje zastavlja v zadnjem desetletju in sovpada $\mathrm{z}$ dvema pojavoma: $z$ napredkom novih tehnologij za nevrološke in fiziološke raziskave, zlasti raziskavami možganskih reakcij z zmožnostjo »upodabljanja možganskih procesov" (t.i. »brain imaging"), in s čedalje lažjim dostopom do "glasb sveta«, kjer primerjalni pristopi tako rekoč silijo $\mathrm{v}$ ospredje raziskav.

Za muzikološke raziskave je bolj ali manj značilno, da se večinoma osredotočajo na partikularne teme, zamejene večinoma na družbene ali geografske skupine, tako da kljub vrednim poskusom bolj holistično naravnanih raziskav, ki posredujejo med bolj $\mathrm{k}$ naravoslovju ( $\mathrm{k}$ »trdim « znanostim) usmerjenimi raziskovalnimi postopki, in tistimi iz humanistično-družboslovnih (»mehkih«) ved, ostaja naloga povezovanja raziskav o glasbenih preferencah obsežna tema, ki ne ponuja utečenih raziskovalnih postopkov in

12 Prim Annirudth D. Patel. 'The Relationship of Music to the Melody of Speech and to Syntactic Processing Disorders in Aphasia'. V: The Neurosciences and Music II: From Perception to Performance, Volume 1060, published December 2005. Annual of the New York Academy of Science 1060 (2005), 59-70. - Zlasti pa gl.: isti. predavanje 'Language, music, and the brain: A resourcesharing framework's simpozija simpozija Language and Music as Cognitive Systems, Cambridge University, 11. - 17. 5. 2007. Dostop. 20.7.2007 na http://vesicle.nsi.edu/users/patel/publications.html. 
ne kakega »kataloga vprašanj«. Tako kljub razmeroma bogati množici podatkov o posameznih plateh glasbenih struktur danes obstaja tako na področju recepcije kot teorije glasbe samo nekaj orisov »integrativnega mišljenja «, ${ }^{13}$ ki združujejo razlike med vprašanji »kulture in »nature«, za katere je mogoče reči, da postopoma dobivajo priznanja širšega kroga raziskovalcev. Med temi kaže v prvi vrsti omeniti The 1999 Ernest Bloch Lectures - Music and Mind: Foundations of Cognitive Musicology in Sweet Anticipations. Music and the psychology of expectation (2006) Davida Hurona, This is your brain in music (2006) Daniela J. Levitina ter delo Iana Crossa v zadnjem desetletju. In Bemetzriederjevo vzporednico med govorom in glasbo je treba uvrstiti k tovrstnim raziskavam, ki odpirajo starožitno problematiko povezav med »naravno« in »kulturno« pogojenostjo glasbe. Glasbene strukture so v njegovem pogledu stične točke med bistvenim in obrobnim, med ključnim in naključnim, v končni fazi med univerzalnim in partikularnim.

$\mathrm{V}$ muzikološki literaturi je premislek o univerzalijah razpršen: med prve sodobne poskuse opredelitve glasbenih univerzalij pod tem imenom (doslej brez večje odmevnosti) sodijo avtorji zbornika s simpozija Les Universaux en musique s sredine devetdesetih let 20. stoletja. ${ }^{14}$ Čeprav glasbene univerzalije že dolgo sodijo k muzikološkim temam, osrediščenim v reku "glasba je univezalni jezik «" ${ }^{15}$ in so vedno znova privlačile raziskovalno zanimanje, ${ }^{16}$ se zdi refleksija o glasbenih univerzalijah "abgelöst durch Erforschung von kulturspezifischen autonomen Musikgeschichten $«{ }^{17} \mathrm{Kljub}$ raziskovalni privlačnosti vprašanja o glasbi kot človeški univerzalni kompetenci (I. Cross), ${ }^{18}$ ki tvori pomemben kontrapunkt h kulturološkim raziskavam glasbe, nekateri raziskovalci v zadnjih dveh desetletjih ponujajo tehtne raziskovalne predloge, ki opozarjajo na potrebo po povezovanju med seboj sicer nepovezanih partikularij. Za načelno ilustracijo teh prizadevanj je mogoče omeniti recimo Tarastijevo zamisel o dveh vrstah pomenoslovnih interpretacij: Tarasti razlikuje med "philosophical 'style' rather than a systematic classification« in sistematsko klasifikacijo utemeljeno na prepričanju »that all signs exist only on the basis of an order which is there before the scholar starts his/her work«.19

13 Gerhard Engel. 'Musiksoziologie im Konzert der Wissenschaften'. In: Christian Kaden / Karsten Mackensen, Soziale Horizonte von Musik. Ein kommentiertes Lesebuch zur Musiksoziologie. Kassel et al.: Bärenreiter (Bärenreiter Studienbücher Musik, Hrsg. Von Silke Leopold und Jutta Schmoll-Barthel, Band 15) 2006, 226.

14 Costin Marieanu / Xavier Hascher (ur.). Les Universaux en musique. Actes du quatrième congrès international sur la signification musicale tenu à Paris, en Sorbonne du 9 au 13 octobre 1994. Paris: Publications de la Sorbonne 1999.

15 Rudolf Maria Brandl / Helmut Rösing. 'Musikkulturen im Vergleich'. V: Herbert Bruhn / Rolf Oerter / Helmut Rösing. Musikpsychologie - Ein Handbuch. Reinbek bei Hamburg: Rohwolt Taschenbuch Verlag Gmbh ${ }_{4} 2004,58$.

16 Herbert Bruhn. 'Tonpsychologie - Gehörpsychologie - Musikpsychologie’. V: Herbert Bruhn / Rolf Oerter / Helmut Rösing. Musikpsychologie - Ein Handbuch. Op. cit. 447-448.

17 Rudolf Maria Brandl / Helmut Rösing. 'Musikkulturen im Vergleich'. Op. cit., 58.

18 Ian Cross. 'Music, Cognition, Culture, and Evolution'. In: Annals of the New York Academy of Sciences 2001/930, 28-42.

19 Četudi Tarasti govori o semiotiki glasbe, njegova misel v osnovi velja za raziskovanje glasbe v najširšem pomenu razumevanja glasbe. Zaradi jasnosti navajam odlomek: »I have classified all the musical semiotic theories - in the epistemic sense - into two groups, the first of which starts with rules and grammars belonging to all music, emphasizing music's surface, which supposes that before the rules set by a theoretician there is just nothing - and consequently when the rules stop their functioning there remains nothing. This type of semiotics, as a philosophical 'style' rather than a systematic classification, I would call as 'classical' semiotics. [...] The other trend is to think that all signs exist only on the basis of an order which is there before the scholar starts his/her work and which remains there when he/she has finished. This semiotic philosophy approaches the meaning (1) as a process, i.e. supposing that signs cannot be defined without taking into account the time, place and subject (actor), (2) as something immanent, i.e. believing like Mead and Merleau-Ponty primarily that meaning is produced within a given system, body, organism, in the first place without any meaning coming from outside as a deus ex machina (like in the 'redemption' at the end of Chausson's piece, the reconciling themes do not stem from outside but are generated from the materials within the piece); (3) by giving emphasis to the content, the signified, which however, can be something non-verbal, 'ineffable', expressible only in terms of a quasi-corporeal experience. Eero Tarasti. 'The Emancipation of the Sign: On the Corporeal and Gestural Meanings in Music'. In: Applied Semiotics / Sémiotique apliquée (AS / SA) Issue Nº / Numéro 4, 188-9. 
Prav ta razlika med epistemološko sistematizacijo kot komplementarnim protipolom bolj naključno povezanega opisovanja - z besedami Clifforda Geertza: med "podrobnostno« (»thin«) naravnanim pogledom kot dopolnilom »široko« (»thick») zastavljenega opisa - napeljuje k primerjavam različnih "pomenskih" plasti glasbe. Ne le muzikologija, metodološko bi bilo v imenu meddisciplinarnega raziskovanje glasbe ${ }^{20}$ nujno treba ponuditi razdelane vezi med pojmi, ki opisujejo isti pojav z različnih spoznavnih plati. Denimo, kakšno je razmerje med konceptom geste, kot ga obravnavajo tako semiologi glasbe kot raziskovalci popularne glasbe (recimo R. Hatten in R. Middleton), ${ }^{21}$ in glasbenoteoretskim pojmomformalne vsebine (»Formgehalt»), ki ga je predlagal Albrecht von Massow? ${ }^{22}$ Gre za terminološko konkurenco ali analitično ločena koncepta označevanja „formalnih vsebin «? Odzivna Massowo, v jedru greimasovsko skovanko Formgehalt pričajo o težavnosti opuščanja stare antinomije med formo (strukturo, »notranjim pomenom») in vsebino (izrazom, pomenskostjo): dvome v smiselnost tovrstnega neologizma je v odzivih raziskovalcev na Massow predlog obenem vseskozi spremljalo nezadovoljstvo nad to delitvijo, čeprav alternative ni ponudil nihče od tistih, ki so se pisno odzvali na njegov predlog (medtem ko vprašanja o potrebnosti vzporejanja konceptov za različne plati opredeljevanja istega pojava med njimi ni nihče načel). ${ }^{23}$

Podobno je s pojmovanjem glasbenih univerzalij. Čeprav obstaja vrsta muzikološko relevantnih besedil, kjer so glasbene univerzalije vključene v razpravo, ${ }^{24}$ bi mogli naslednji štirje primeri ponuditi zadovoljiv vpogled na obravnavo pojma danes. Če je Bruno Nettl previdno predlagal centrifugalen pogled na glasbene univerzalije, osrediščene v glasbenih strukturah in iščoč »zunanje» kulturne vsebine, in je Vladimir Karbusicky

20 Za interdisciplinarnost $\mathrm{v}$ muzikologiji se zdi, da je kljub teoretski veljavi praktično še v povojih in da z vzpostavitvijo mednarodnega muzikološkega simpozija o interdisciplinarne raziskovanju, ki ga je iniciral graški psiholog glasbe Richard Parncutt leta 2004, dobiva (znova) konkretne pobude.

21 Robert S. Hatten. Interpreting Musical Gestures, Topics, and Tropes. Mozart, Beethoven, Schubert, Bloomington and Indianopolis: Indiana University Press (Musical Meaning and Interpretation series, ur. Robert S. Hatten) 2004. Isti. 'Four Semiotic Approaches to Musical Meaning: Markedness, Topics, Tropes, and Gesture'. V: Muzikološki zbornik / Musicological Annual 41, Ljubljana: Department of Musicology 2005, 5-30. Richard Middleton. 'Popular music analysis and musicology: Bridging the Gap'. In: Popular music 12 (1993), str. 175-90. Richard Middleton. 'Locating the People, Music and the Popular'. V: Martin Clayton, Trevor Herbert, Richard Middleton (eds.): The Cultural Study of Music - a critical introduction. New York, London: Routledge 2003, 251-262.

22 Albrecht von Massow. 'Musikalischer Formgehalt'. V: Archiv für Musikwissenschaft 1992, LV/4, 269-287.

23 Constantin Floros. 'Form und Gehalt in der Musik'. V: Archiv für Musikwissenschaft 1999, LVI/1, 71-72. - Jaroslav Jiránek. 'Kunst und ästhetisches Subjekt'. V: prav tam, 72-76. - Helga de la Motte. 'Formgehalt ein Begriff mit begrenzter Reichweite?'. V: prav tam: 76-77. - Schwab-Felisch, Oliver. 'Eigenschaft oder Aspekt?'. V: prav tam, 77-79.

24

Prim. recimo: Marta Grabócz. 'Formules récurrentes de la narrativité dans les genres extra-musicaux et en musique'. V: Marieanu, Costin / Hascher, Xavier (ur.). Les Universaux en musique. Actes du quatrième congrès international sur la signification musicale tenu à Paris, en Sorbonne du 9 au 13 octobre 1994. Paris: Publications de la Sorbonne 1999, 67-86. - Michel Imberty. 'The Question of Innate Competencies in Musical Communication'. V: Wallin, Niels L. / Merker Björn / Brown, Steven (ur.). The Origins of Music, Cambridge, Massachusetts, London: MIT Press 2001, 449-462. - Jaroslav Jiránek. 'Quelques réflexions sur les constantes de la sémiantique musicale'. V: Marieanu, Costin / Hascher, Xavier (Eds.). Les Universaux en musique. Actes du quatrième congrès international sur la signification musicale tenu à Paris, en Sorbonne du 9 au 13 octobre 1994. Paris: Publications de la Sorbonne 1999a, 59-65. - Joseph Kon. 'Einige Bemerkungen über das Problem der musikalischen Universalien'. V: Marieanu, Costin / Hascher, Xavier (ur.). Les Universaux en musique. Actes du quatrième congrès international sur la signification musicale tenu à Paris, en Sorbonne du 9 au 13 octobre 1994. Paris: Publications de la Sorbonne 1999, 197-205. - François-Bernard Mâche. 'The Necessity of and Problems With a Universal Musicology'. V: Wallin, Niels L. / Merker Björn / Brown, Steven (Eds.). The Origins of Music, Cambridge, Massachusetts, London: MIT Press 2001, 473-480. - Jean-Jacques Nattiez. 'Is the Search for Universals Incompatible with the Study of Cultural Specificity?' John Blacking Memorial Lecture, Venezia: XX European Seminar in Ethnomusicology (ESEM) 29 settembre - 3 ottobre 2004 Venezia - Isola di San Giorgio Maggiore http://217.57.3.105/cinipdf/vari/blaking.pdf (dostop: 4. januar 2007). - Bruno Nettl. 'On the Question of Universals'. V: The World of Music, Vol. XIX (1977), no 1/2. - Isti. 'An Ethnomusicologist Contemplates Universals in Musical Sound and Musical Culture'. V: Wallin, Niels L. / Merker Björn / Brown, Steven (Eds.). The Origins of Music, Cambridge, Massachusetts, London: MIT Press 2001, 463-472. - Sandra Trehub. 'Human Processing Predispositions and Musical Universals'. V: Wallin, Niels L. / Merker Björn / Brown, Steven (ur.). The Origins of Music, Cambridge, Massachusetts, London: MIT Press 2001, 427-448. 
našel prepričljive argumente za prikaz univerzalnih podob glasbene oblike z antropološkim raziskovalnim aparatom, je Leonard B. Meyer - jasno razlikujoč »sintaktične« (»syntactic«, "perceptually discrete») in »statistične» (»statistical«, »relational«) kognitivne univerzalije (»cognitive universals«) glasbenega toka - podal utemeljene razloge za ponovni premislek o glasbenih univerzalijah kot vredni glasboslovni teoriji. ${ }^{25}$ Obenem je Meyer posvaril glede pojma "glasbena univerzalija«: "There are none. There are only the acoustical universals of the physical world and the bio-psychological universals of the human world «. ${ }^{26}$ Četrti muzikolog, ki ga kaže omeniti, je Jean-Jacques Nattiez. ${ }^{27}$ Njegov navdihnjeni prikaz glasbenega pomena vključuje razloček, po Jeanu Molinoju, med »universals of strategy« and »universals of substance«. Nattiezov pogled priča o živem zanimanju za glasbene univerzalije, nemara še bolj miselno živahnem kot so tisti pri Nettlu, Meyerju in Karbusickem. Vsem štirim je pa skupno, da skušajo opredeliti vezi med »notranjo zgradbenostjo« glasbe in njihovimi »zunanjimi pomeni«.

Kljub razlikam omenjeni koncepti glasbenih univerzalij dopuščajo pokazati na osnovno vez, na elementarno stično točko. Pojem glasbena univerzalija - kot je poudaril Nattiez v svojem prispevku, a je mogoče njegovo stališče sprejeti kot skupno izhodišče, poleg drugih, tudi vseh štirih zgoraj omenjenih avtorjev - stopa na stran raziskav »of a well thought-out reconciliation of the universal and the relative, of the innate and the acquired, of nature and culture ${ }^{28}{ }^{2} \mathrm{Na}$ področju teorije glasbe denimo pomik k povezovanju "naravnih" in »kulturnih" danosti, ki zadevajo glasbo, dobiva pomembno vlogo $\mathrm{v}$ okviru teorije toposov. Robert Hatten je elegantno zaobjel spoznavoslovni obseg glasbenih toposov, te verjetno najbolj znane teorije glasbenosemiotske in hermenevtične analize, ki so jo različni avtorji razvijali izhajajoč predvsem iz dela Leonarda Ratnerja Classical Music. Expression, Form, and Style (1980). Pri obravnavi štirih ravni interpretiranja glasbenega pomena je Hatten opredelil naslednja pomenska polja: 1. markedness ali izrazitost kot osnovno obliko »sintaktičnega smisla» (»meaningful syntax»); 2. topics ali topos kot »larger style types with stable correlations and flexible interpretative ranges«; 3. troping ali tropiranje kot proces kombiniranja dveh (ali več) toposov v topose drugega reda ali »inherentno glasbeno prispodobo« (»inherently musical metaphor ); 4. musical gesture ali glasbena gesta kot interdisciplinarni koncept "vključujoče teorije» ("comprehensive theory«), ki bi omogočila »to capture the more synthetic character of music ${ }^{29}$ Hattenova teorija pravzaprav dopušča zastaviti naslednje vprašanje, četudi ne on in ne drugi raziskovalci ne ponujajo odgovora nanj: ali je potemtakem koncept glasbene univerzalije spoznavna vzporednica glasbenoanalitske kategorije glasbene geste?

25 Bruno Nettl. 'On the Question of Universals'. Op. cit. - Isti: 'An Ethnomusicologist Contemplates Universals in Musical Sound and Musical Culture'. Op. cit. - Vladimir Karbusicky. Kosmos-Mensch-Musik. Hamburg: Verlag R. Krämer 1990. - Isti. 'Musikalische Urformen und Gestaltungskräfte'. V: Otto Kolleritsch (ur.). Musikalische Spannungsfeld von Chaos und Ordnung, Studien zur Wertungsforschung, Band 23, Gaz: Universal Edition 1991. - Isti. 'Anthropologische und naturgegebene Universalien in der Musik'. V: Marieanu, Costin / Hascher, Xavier (ur.). Les Universaux en musique. Actes du quatrième congrès international sur la signification musicale tenu à Paris, en Sorbonne du 9 au 13 octobre 1994. Paris: Publications de la Sorbonne 1999, 137-154. -Leonard B. Meyer. ,A Universe of Universals'. IN: The Journal of Musicology, Volume XVI, Number 1, Winter 1998, $3-25$.

26 Leonard B. Meyer. 'A Universe of Universals'. Op. cit., 6. Za identično razmejitev s stališča recepcije glasbe prim. še uvodno poglavje knjige Daniela J. Levitina This is your Brain in Music (New York: Duton [Penguin Group, USA] Inc., 2006, zlasti str. 14-17).

27 Jean-Jacques Nattiez. 'Is the Search for Universals Incompatible with the Study of Cultural Specificity?' Op. cit.

28 Prav tam, 19.

29 Isti. 'Four Semiotic Approaches to Musical Meaning: Markedness, Topics, Tropes, and Gesture'. Op. cit., 14-15. 
Kljub temu, da bi bilo problematično bodisi zanikati bodisi pritrditi, ostaja nevprašljivo dejstvo, da imata oba pojma - muzikološki koncept glasbene univerzalije in glasbenoteoretski pojem gesta - isti cilj: opredeliti »samoemancipirajoči znak« $v$ glasbi s tistimi pomenskimi plastmi, ki jih je mogoče določiti spričo njegove »naravne« in »kulturne"pregnance.

Prav ta pomik utemeljevanja v smeri od narave h kulturi je značilen tudi za Bemetzriederjev spis Glasbena toleranca. K drugemu delu izpeljevanja, ki ga je Bemetzrieder nakazal v zadnjem navedenem odstavku in ki izhaja iz dvoma v obstoj univerzalnega glasbenega jezika - iz dvoma, da je musica perennis sploh mogoča -, sodi sklop argumentacije, ki ga nakazuje zadnji odstavek Bemetzriederjevega spisa s primerjavo glasbenih manir treh mojstrov 18. stoletja, ki utelešajo tri "glavne glasbe Evrope«: Monsignija, Glucka in Piccinija. Za razliko od nedvoumnih jezikovnih vzporednic prvega argumentacijskega sklopa - osrediščenega v teoretsko tudi danes pomembnem pojmu o »univerzalijah gasbe« in analitičnih analogijah med jezikom in biološkimi lastnostmi človeka ter glasbo - v naslednjem argumentacijskem sklopu, kjer se prepletajo osebnostno psihološka in estetska vprašanja, sledimo seriji "pomožnih določil«, ki se iztečejo v tri glavna gibala glasbe: občutljivost, moč in prefinjenost. V duhu (operne) estetike okusa 18. stoletja, ki odpira več vprašanj kakor pa ponuja odgovorov na začrtano opredeljevanje nacionalne identitete, jih Bemetzrieder prizna vsem trem nacionalnim glasbenim kulturam:

Messieurs Gluck \& Piccini abandonnent sensiblement leurs manieres naturelles, \& s'efforcent tous deux de devenir François; mais ils ne sont pas encore toutà-fait naturalisés parmi nous, on reconnôit leurs premieres habitudes: l'un fois germanise, \& l'autre souvent italiénise ...

Je prie le Lecteur de ne pas penser que je veuille critiquer ces deux hommes célèbres; j'admire l'un \& l'autre. Le Roland de M. Piccini me paroît un prodige de mérite; l'Auteur, en apprenant notre langue, a fait un chef-d'oeuvre de Musique; on voit ses progrès dans son Ouvrage: le troisieme acte est beaucoup plus françois que les deux premiers, \& la scène ajoutée, qui termine les fureurs de Roland, a la simplicité \& la noblesse qui caractérisent notre expression: sans blesser l'organe, une Musique forte saisit, étonne, intéresse \& peint à l'imagination tous les mouvemens de la douleur \& du désespoir d'un Héros trahi par l'amour: une certaine délicatesse du chant de toutes les parties, même dans
Gospoda Gluck in Piccini rahločutno opuščata svoje naravne manire in si prizadevata postati Francoza; a še vedno nista povsem naturalizirana med nami in prepoznamo njune prvotne navade: prvi germanizira, drugi pa pogosto italijanizira ...

Prosim bralca, naj ne misli, da želim kritizirati oba slavna moža; občudujem tako enega kot drugega. Roland gospoda Piccinija se mi zdi čudež velikih odlik in avtor, ki se je medtem učil našega jezika, je ustvaril glasbeno mojstrovino; v tem delu je videti njegov napredek: tretje dejanje je veliko bolj francosko kot prvi dve dejanji, dodana scena, ki sklene Rolandove strasti, pa vsebuje preprostost in plemenitost, ki karakterizirata naš izraz: brez škodovanja telesu, glasba močno prevzame, osupne, pritegne in domiselno upodablja vsak gib bolečine in obupa junaka, ki ga je izdala ljubezen; po določeni nežnosti pesmi vseh vlog, celo v trenutkih največje zmedenosti, prepoznamo francoskega heroja. 
les instants du plus grand égarement, font reconnoître le Héros François. [20]

Je dois un double tribut à M. Gluck pour chacun de ses Opéra; son Armide, ses deux Iphigénies, son Alceste \& son Orphée ont droit à la reconnoissance des Allemands \& des François*; les uns \& les autres peuvent trouver dans ces Ouvrages immortels tout ce que leur expression a de plus sublime. Je fais de bon coeur hommage à ce rare génie: il nous a enrichi d'une forme nouvelle; sa Musique marche avec le poëme, chaque acte ne paroît être qu'un seul morceau: il abandonné ce froid \& ennuyeux récit, ainsi que cette mélodie recherchée, qui rarement intéressent, pour leur substituer un chant simple \& naturel, qui suit toujours le sens des paroles. L'orchestre n'est plus un simple accessoir agréable, c'est le suplément du chant qui suit toujours la poésie de l'Ouvrage, fortifie \& augmente l'expression, peint tantôt les physique du lieu, de la situation, \& rend tantôt les mouvemens, les gradations, les agitations du coeur \& de l'ame, qui échappent à la voix \& à la parole: C'est surtout dans son [21] Armide \& dans sa derniere Iphigénie, que paroît dans tout son jour cette Musique dramatique ... Si les chef-d'oeuvres de M. Gluck ne sont pas du mode François, d'un bout à l'autre, \& s'il me force de temps en temps d'interpréter mes sensationes en langue Allemande, je lui suis d'autant plus redevable; j'aime assez à me rappeller les premieres années de mes jouissances ...

La différence de ces trois modes de l'expression musicale est assez bien sentie ajourd'hui à Paris, mais on l'examine fort peu: chacun adopte un mode \& dédaigne les les deux autres, tous les trois sont applaudis \& critiqués: jamais l'esprit de parti

Je ne peux pas parler de son Echo \& Narcisse, je ne l'ai entendu que deux fois, \& je n'ai pas encore vu la partition.
Dvojni poklon dolgujem gospodu Glucku za vsako njegovih oper: Armida, obe Ifigeniji, Alceste in Orfej so upravičene, da jih spoznamo tako za nemške kot francoske**. Tako Nemci kot Francozi lahko v tej nesmrtni glasbi najdejo vse, kar ima njihov izraz najbolj sublimnega. Rade volje se priklanjam temu redkemu geniju: obogatil nas je z novo formo; njegova muzika koraka s pesmijo, vsako dejanje je zaokroženo v samostojen del: izognil se je tej hladni in dolgočasni pripovedi ter izumetničeni melodiji, ki sta redko zanimivi, in ju nadomestil s preprostim in naravnim petjem, ki vselej sledi smislu besed. Orkester ni nič več samo prijeten spremljevalec, temveč sooblikuje pesem, ki vselej sledi poeziji, krepi in razširja njen izraz, včasih slika podobo prostora, situacije, včasih zrcali gibanje, stopnjevanje, razburjenost srca in duše, ki uhajajo glasu in besedam. Ta dramatična glasba se v vsem svojem blesku pojavlja predvsem v njegovi Armidi in v njegovi zadnji Ifigeniji ... Če mojstrovine gospoda Glucka niso ukrojene po francoski modi od začetka do konca in če me občasno sili, da svoje zaznave interpretiram v nemškem jeziku, sem mu toliko bolj hvaležen; precej rad imam spomin na prva leta svojih užitkov ...

Razlika med temi tremi načini glasbenega izraza je precej dobro zaznavna v današnjem Parizu, a je premalo raziskana: vsak sledi enemu načinu in prezira druga dva, vsem trem ploskajo in vse tri kritizirajo. Strankarski duh nikoli ni tako dobro shajal, ker so vse tri glasbe enako dobre; Francozi in Nemci korakajo k popolnosti, Italijani so jo presegli, vsi trije dosegajo eno raven cilja in so posledično dovzetni za hvale in graje. Občutljivost, moč in prefinjenost - te tri osnovne kvalitete izraza

** Ne morem govoriti o njegovi operi Echo \& Narcisse, saj sem jo komajda dvakrat slišal in partiture še nisem videl. 
n’a si bien rencontré, car les trois Musiques sont également bonnes; la Françoise \& l'Allemande cheminent vers la perfection, l'Italienne l'a dépassé, toutes les trois ont à un degré du but \& par conséquent également susceptibles d'éloges \& de critiques. Délicatesse, force \& finesse, ces trois principales qualités de l'expression, sont leurs devises: mais les François \& les Allemands prennent encore parfois, les uns la pauvreté pour la délicatesse, \& les autres le bruit pour la force. Les Italiens commencent à être trop maniérés, ils [22] remplacent souvent leur finesse par la subtilité, \& la matiere subtile n'est plus à la portée de nos sens. so njihove devize: a Francozi in Nemci še vedno včasih jemljejo - prvi bornost za občutljivost, drugi grobost za silo. Italijani začenjajo zapadati v manirizem, pogosto zamenjujejo svojo prefinjenost za subtilnost, subtilna snov pa že ni več v dometu naših čutov

Občutlivost, moč in prefinjenost (Délicatesse, force, finesse) glasbe so po Bemetzriederju pokazatelji nove forme: so učinki mojstrovin, ki (ne glede na italijaniziranje, germaniziranje ali francosko modo) presegajo kulturne ločnice med tremi nacionalnimi glasbami. Avtor zajame novo glasbeno formo še najbolj jasno ob oceni Gluckovih oper, ki da prinašajo, kar je najbolj sublimnega v glasbi tistega časa. To je zlasti dvoje: 1. »naravno petje« in neizumetničena melodika, ki tesno sledi dikciji jezika, in pa 2. izrazna dodelanost instrumentalnega parta, ki zmore neposredno ujeti neizrekljive odtenke povednosti in nadgrajuje besedilo na različnih semantičnih ravneh tako, da si Gluckova dela zaslužijo epiteton »dramatična« bolj v duhu estetike vsebine 19. stoletja kot operne estetike 18. stoletja.

Vprašanje nacionalnega v glasbi se torej na tej točki izkaže za postransko: pomembna je estetska kakovost, h kateri naj stremi tudi nacionalna glasba (čeprav jo je - po sorodnih ali drug(ačn)ih merilih - mogoče iskati pri vsaki glasbi). Medtem ko Bemetzriederjevo izvajanje vodi k relacijskim temam recepcije glasbenih univerzalij, je o danes vrednih prizadevanjih opredeljevanja nacionalnega v glasbi mogoče reči, da poglabljajo metodološka vprašanja o deležu substance,jedra,podstati nacionalnega. Raziskave nacionalne identitete danes terjajo premislek o strukturnih glasbenih univerzalijah in njihovi pomenski prepustnosti, kot je mogoče razbrati iz naslednjega primera iz odziva na delo Marije Bergamo. Marija Bergamo je formulirala nacionalno v glasbi z adornovsko zamislijo o usedlinah narodovih (pra)podob takole: »Erstens könnte man das musikalische Material im Adornschen Sinne vor allem in uralten, aber auch alten und lebendigen volksmusikalischen Schichten suchen, die wie ein empfindlicher Seismograph die lebhaften Fermentierungen und ständigen verschiedenen Erneuerungen in Verhältnis zur fernen ursprünglichen Überlieferung aufzeichnen. Für die nationalen Kulturen waren (und sind) sie von großer Bedeutung. ${ }^{30}$ A njen nadaljnji sklep opozarja na metodološko zadrego, s katero bi se bili morali spopasti: „Der rein musikalische Sinn aber, der nicht von außen kommt, sondern von ‘innen', aus den musikalischen Zusam-

30 Marija Bergamo. 'Versuch zum musikalisch Nationalen'. V: International Review of the Aesthetics and Sociology of Music 20 (1989:2), 169-181. 
menhängen selbst [...] ist nicht eindeutig festgelegt und kann dies auch nicht sein. Wenn man ihn nicht nur als innermusikalische Logik, sondern als vor allem ästhetisch wahrnehmbare und emotional gekennzeichnete Kategorie verstehen möchte, dann kann man das Nationale nur als potentiellen Teilnehmer am Prozeß der Sinngewinnung [...] verfolgen« Svarilo, ki ga je iz Bergamovinega stališča do analitičnega prikaza glasbene nacionalne identitete potegnila Ursula Geisler, se pomenljivo glasi: »Es ist gerade die Wirkung von Musik auf Emotionen, die individuelle und kollektive Rezeption, der mit Schriftsprache so schlecht beizukommen ist. Eine Analyse, wie die von Bergamo geforderte, scheitert an ihrer Umsetzbarkeit, auch am Mangel einer zufriedenstellenden terminologischen Ausgangssituation. « ${ }^{31}$ Tako se vprašanje nacionalnega ob navedenih stališčih Marije Bergamo in Ursule Geisler kaže v prvi vrsti kot metodološko, ne tematsko: nihče ne dvomi, da je (nacionalna) identiteta substančna in relacijska obenem, nasprotno pa ostajajo problematična vprašanja o deležu in vzvodih za prevlado ene ali druge plati, ki sooblikujeta nacionalno identiteto.

Zgoraj navedeno opozorilo Ursule Geisler o »neprestavljivosti analize«, kakršno zahteva Marija Bergamo, meri na to, da je analitično domala nemogoče učinkovito zasledovati sicer tudi po njenem edino smiselni opredeljenosti nacionalne identitete kot skupka različnih kakovosti "udeležencev v procesu pridobivanja smisla« (M. Bergamo). Geislerjinega stališča ne kaže razumeti kot razglas spoznavnega neuspeha: ko avtorica upravičeno opozarja na »manko zadovoljive izhodiščne terminološke situacije«, govori o pragmatični zadregi muzikologije, ki ne ponuja konsenza o hierarhijah, določilih ali plasteh "udeležencev« procesa, skozi katerega se tvori nacionalna identiteta. Zanj je značilno, da terja meddisciplinarno obravnavo: vključuje »dejavnike življenja«, vključuje vse plati umeščenosti glasbe v okolje. In nadaljevanje Bemetzriederjevega spisa prinaša umestitev nacionalne glasbe v širše kulturno okolje - prinaša kritično kulturološko skico glasbenega življenja ob koncu 18. stoletja. Ta ne vsebuje novih argumentov o (nacionalni) identiteti, pač pa polemizira o enem od glavnih razlogov za prevlado italijanske glasbe: o neutemeljenem prepričanju v njeno superiornost. Čeprav Bemetzrieder priznava popolnost italijanski glasbi, ki da že zapada v manirizem, od te točke naprej nagovarja rojake Francoze z danes nekoliko preveč apologetskimi stališči, da bi jih mogli razumeti kot resnejšo kulturološko skico. Kljub temu pa tudi nadaljnji odlomek, ki bi ga kot tretji sklop argumentacijskega loka mogli označiti za kulturološkega, prinaša zgovorne podrobnosti o družbenem ozračju v Franciji in Evropi tistega časa:

Je ne sais si \& quand les Italiens reviendront à la perfection, mais je crois que nous cheminerons encore longtemps, avant de l'atteindre: il y a tant de causes naturelles qui nous arrêtent en chemin. Les Italiens seuls ont pu marcher sans obstacles; nul modele de chant, ni de Musique, ne pouvoit les tenter, ni
Ne vem, ali in kdaj se bodo Italijani vrnili k popolnosti, ampak verjamem, da je naša pot do nje še dolga: tako številni so naravni vzroki, ki nam stojijo na poti k njej. Le Italijani so lahko napredovali brez ovir; noben vzor petja ali glasbe jih ni mogel premamiti ali zapeljati: načina

31 Ursula Geisler. '”... die Skalden waren die Brüder der Barden«. Aspekte schwedischer und deutscher Nationallied-Konstruktionen', Die kulturelle Konstruktion von Gemeinschaften im Modernisierungsprozeß: Schweden und Deutschland - Arbeitspapiere, Band 10, 1997 (ISBN 3-932406-11-7). Citirano po: http://www2.hu-berlin.de/gemenskap/inhalt/publikationen /arbeitspapiere/ahe_10.html\#N_63_ 
les séduire: la maniere de noter des anciens est encore ignorée aujourd'hui. Les Italiens furent obligés de perfectionner leur chant naturel \& de créer une Musique, à mesure qu'ils perfectionnerent leur langage \& leur poésie. Nous sommes venus après eux, pour perfectionner notre langue, nous avons fait comme eux, nous avons étudié les chefd'oeuvres de discours \& de poésies des Grecs \& des Romains, nous nous sommes enrichis de leurs idées \& de leurs images, nous avons cherché à les exprimer à Françoise; mais pressés de jouir de nos premieres productions, nous avons pris les Italiens pour modeles, nous avons ajousté leur chant perfectionné à notre poésie naissante, \& leur Musique à nos chef-d'oeuvres. Les autres Peuples del'Europe, plus pressés [23] encore, ont tout uniment transplanté dans leur Pays la poésie Italienne avec sa Musique.

Cet empressement de jouir a vicié l'organe par-tout: on supporte ajourd'hui sans peine un rythme \& une prononciation musicale contraire à l'accent de la langue, toutes les oreilles sont habituées à un chanter discordant avec parler: la poésie nationale seule pourra corriger ce premier vice, c'est en France où elle a fait le plus de progrès; il y a déja à Paris quelques oreilles sensibles à l'harmonie des vers, qui se révoltent contre toute mélodie étrangere; \&, si APOLLON continue à répandre ses charmes en Angleterre \& Allemagne, la mélodie Italienne pourra bien un jour être renvoyée, avec la poésie de Metastaze, dans son Pays natal.

Cette révolution pourtant ne se fera pas de si-tôt, de secondes causes retarderont partout les progrès de la Musique nationale: le grand principe, tous les Arts se tiennent, égarera encore bien du monde: sans examiner, on dira encore souvent, il est de la Musique comme de la Peinture, c'est en Italie qu'il faut les étudier, c'est-là où est le berceau \& l'école des beaux Arts. [24] Une foi aveugle zapisovanja starih še danes ne poznajo. Italijani so bili prisiljeni izpopolniti svojo naravno pesem in ustvariti glasbo ob tem, ko so izpopolnili svoj jezik in svojo poezijo. Mi smo z izpopolnjevanjem svojega jezika hodili za njimi, naredili smo enako kot oni: učili smo se iz mojstrovin jezika in pesnikov Grčije in Rima, obogateli smo z njihovimi idejami in podobami, ki smo jih skušali izraziti po francosko; a v naglici, da bi uživali v naših prvih sadovih, smo si vzeli Italijane za vzgled, prilagodili njihovo izpopolnjeno petje naši porajajoči se poeziji ter njihovo glasbo našim mojstrovinam. Druga ljudstva Evrope, ki se jim je še bolj mudilo, so italijansko poezijo z njeno glasbo preprosto presadila v svojo deželo.

Ta vnema po uživanju je povsod spodkopala telo: danes se brezskrbno prenašata glasbeni ritem in izgovorjava, ki nasprotujeta akcentom jezika, vsa ušesa so vajena petja, ki je razglašeno z govorom: samo nacionalna poezija bo mogla popraviti to pregreho, ki se je v Franciji najbolj razpasla. V Parizu so se nekatera na harmonijo verza občutlijiva ušesa že uprla zoper vsako tujo melodijo; če bo Apolon še nadalje razpredal svoje čare po Angliji in Nemčiji, se bo italijanska melodika mogla nekega dne, skupaj s poezijo Metastaza, vrniti v svojo rojstno deželo.

Ta revolucija pa se ne bo izvršila tako hitro, drugi vzroki bodo povsod upočasnili napredek nacionalne glasbe: véliko načelo, po katerem se vse umetnosti držijo skupaj, bo dodobra zapeljalo svet - brez podrobne obravnave bo pogosto obveljal rek, da za glasbo velja enako kot za slikarstvo - treba ju je študirati v Italiji, tam je zibelka in šola lepih umetnosti. Slepo zaupanje bo še dolgo družilo Evropo $s$ to zibelko in šolo: amaterji in umetniki drvijo z vseh strani, občudujejo, študirajo 
enchaînera encore longtemps l'Europe à ce berceau \& à cette école: les Amateurs \& les Artistes accourent de tous côtès, admirent, étudient \& retournent dans leur Patrie avec un dédain marqué pour tout talent national:àles entendre, on n'a rien vu, on n'a rien entendu, on ne fait rien, si on n'a pas été en Italie ...

Je ne prononce pas sur tous les Arts, mais ces Voyageurs sont les ennemis les plus implacables de notre Musique, \& cela ne peut pas être autrement; ils apportent en Italie le meilleure volonté d'admirer tout, \& l'effet de la Musique Italienne dans le pays même approche du prodige; les Italiens applaudissent leurs Virtuoses avec transport, ils portent leurs Compositeurs en triomphe ... Ces scènes d'enthousiasme électrisent les Etrangers, \& les enivrent de plaisirs: si une partie de l'expression Italienne échappeà leurs organes, l'admiration supplée \& donne à leurs sensations plus de durée; revenus dans leur Patrie, ils jouissent encore du souvenir: mais ce modele incomparable des plaisirs passés, toujours présent à leur imagination, les rend coupables envers leur Pays; ils n'écoutent plus l'expression [25] qui leur est naturelle, ils dédaignent jusqu'à leur langue; par-tout ils racontent les effets merveilleux quiles ont enchantés; \& la plupart de nos Voyageurs ont beaucoup de mérite, ils enthousiasment \& séduisent tous ceux qui les écoutent, multiplient les partisans del'expression étrangere, \& la Musique Françoise perd peu à peu tous ses appuis. Les Amateurs fideles pourroient craindre la destruction totale, s'il ne restoit pas un défenseur plus puissant que tous les voyageurs. L'organisation Françoise protégera le talent qu'elle a créé: la plus belle langue de l'Europe, qui imprime tous les jours à vingt millions d'hommes son accent, sa mesure, son esprit, des gestes propres \& une physionomie particuliere, saura bien réclamer sa Musique.

Je ne veux pas contester à nos voyageurs François leurs sensations délicieuses: mais in se vračajo $\mathrm{v}$ domovino s poudarjeno zaničevalnostjo do vsakršnega nacionalnega talenta - njih mnenje je, da če kdo ni bil v Italiji, ni upoštevanja vreden, nič ne razume, nič ne dela ...

Ne govorim o vseh umetnostih, ampak ti popotniki so najbolj neizprosni sovražniki naše glasbe - ne more biti drugače. V Italijo prineso najboljšo voljo, da bi občudovali vse, in učinek italijanske glasbe je v Italiji čudežen: Italijani zanosno aplavdirajo svojim virtuozom, svoje skladatelje kujejo v zvezde ... Te scene zanesenjaštva naelektrijo tujce in jih opijajo z užitkom: če del italijanskega izraza uide njihovim zaznavam, ga nadomesti občudovanje, ki njihovim občutkom podaljša trajanje; nazaj v svoji očetnjavi še vedno uživajo v spominih: a zaradi tega modela preteklih užitkov brez primere, ki so vselej prisotni v njihovi domišljiji, postanejo krivični do svoje domovine. Nič več ne slišijo izraznosti, ki je njim naravna, prezirajo vse do lastnega jezika; povsod pripovedujejo o čudovitih učinkih, ki so jih očarali; in večina naših popotnikov ima velike zasluge: njihovo navdušenje in zapeljevanje vseh tistih, ki jih poslušajo, množi pristaše tuje izraznosti, francoska glasba pa malo po malo izgublja vso svojo podporo. Zvesti amaterji bi se lahko bali popolnega uničenja, če ne bi ostal niti en branitelj močnejši od vseh popotnikov. Francoska organizacija bo branila talent, ki ga je ustvarila: najlepši jezik Evrope, ki dnevno dvajsetim milijonom ljudi vtiskuje svoj naglas, svoje mere, svojega duha, svoje lastne geste in posebno fizionomijo - znala bo zahtevati svojo glasbo.

Ne želim oporekati sladkim vtisom naših francoskih popotnikov: verjamem pa, da ni italijanska glasba edini vzrok njihovih užitkov; da bi v resnici taista komična opera, ki se jim je v Italiji zdela tako 
je crois que la Musique Italienne n'est pas la seule cause de leurs plaisirs; qu'ils soient de bonne foi, le même Opéra bouffon qui les a ennivrés en Italie, ne leur a pas fait la même sensation à Londres, à Vienne \& à Paris; on jouit mieux du spectacle quand l'assemblée est nombreuse \& quand les applaudissemens sont universels. L'enthousiasme, [26] le transport \& le fanatisme avec lesquels le Italiens aplaudissent leur Musique, suffiroient pour enivrer un admirateur de bonne volonté.

Les Peintres \& les Sculpteurs sont encore des ennemis terribles de la Musique Française: je ne sais pas pourquoi on adopte si facilement leur opinion; il me semble qu'un sourd \& muet pourroit aussi bien exceller dans leur art qu'un aveugle pourroit exceller dans la Musique....Je ne suis pas étonné que la plupart préferent la Musique Italienne; ils vont tous achever leur talent en italie où ils apportent une oreille vierge qui connoît à peine la chanson des rues. Le dessin \& l'étude de la peinture ou de lasculpture consomment pourl'ordinaire tous les loisirs de leur premiere jeunesse. Arrivés à Rome, ils sont forcés d'écouter la Musique, car en Italie tout est Musique \& tout le monde y est Musicien; s'ils n'apprennent pas, ils deviennent au moins amateurs, \& comme ils ne connoissent point l'expression de leur pays, en peu de tem[p]s ils sont naturalisés pour l'expression Italienne. Je ne suis pas étonné non plus quand j'entends dire à un Peintre qu'il faut aller à l'ecolé de Neaples pour savoir ce que c'est que la Musique, car il n'est pas obligé de connoître tous les Temples [27] d'APOLLON ... Mais je suis singuliérement surpris quand je vois sur la toile une attitude nationale: si je rencontre parfois en peinture les traits extérieurs d'une beauté Française, toujours elle me paroît animée par un souffle étranger; l'ame Grecque ou Romaine qui vivifie les monumens de l'Italie, est toujours au bout de pinceau \& sous le ciseau de l'Artiste, aussi voit-on rarement une ressemblance enkratna, ne naredila nanje enakega vtisa, ko bi jo slišali v Londonu, na Dunaju in v Parizu; užitek nad predstavo je boljši, če je množica številčna in aplavdiranje vsesplošno. Zagnanost, zanos in fanatizem, s katerim Italijani aplavdirajo svoji muziki, zadoščajo za omamo dobrovoljnega oboževalca.

Tudi slikarji in kiparji so nemogoči sovražniki francoske glasbe: ne vem, zakaj njihovo stališče z lahkoto sprejmemo. Zdi se mi, da bi se gluha in nema oseba lahko enako dobro izkazala v svoji umetnosti, kakor bi se mogla slepa izkazati v glasbi ... Ne osupne me, da ima večina rajši italijansko glasbo; svoj talent bodo vsi izpolnili v Italiji, kamor prinašajo svoja deviška ušesa, ki komajda poznajo poulično pesem. Risanje in študij slikanja ali plastike običajno zahtevajo celotnega človeka v njegovi mladosti po cele dneve. Priševši v Rim so prisiljeni poslušati glasbo, kajti v Italiji je vse glasba in tam je vsak glasbenik. Če se ne naučijo, postanejo vsaj amaterji, in ker niso spoznali izraza lastne dežele, se v kratkem naturalizirajo v italijanskem izrazu. Ne osupne me niti, ko slišim reči slikarja, da je potrebno iti v Neapelj, da bi izvedeli, kaj je glasba, saj njemu ni potrebno poznati vseh Apolonovih svetišč ... Toda skrajno osupnem, ko na platnu vidim nacionalno držo: ko včasih v slikarstvu naletim na zunanje poteze francoske lepote, me vedno presenetijo s svojim pridihom tujega. Grško ali rimsko srce, ki oživlja spomenike Italije, je vedno na konici čopiča in vrhu dleta umetnika in tako redko vidimo popolno podobo ... Naj bo to izrečeno brez posledic: na slikarjih in kiparjih je, da nas razsvetljujejo s svojo umetnostjo; namesto da bi kršili svojo pristojnost, namesto da bi hoteli domovini naprtiti drugi jarem, bi si morali prizadevati uničiti predsodke, ki jih držijo vezane na italijansko šolo. 
parfaite ... Que cela soit dit sans conséquence: c'est aux Peintres \& aux Sculpteurs à nous éclairer sur leurs arts; au lieu de franchir leur compétence, au lieu de vouloir imposer à leur patrie un second joug, ils devroient chercher à détruire les préjugés qui la tiennent enchaînée à l'école d'Italie.

L'affabilité française oppose le plus grand obstacle à nos progrès de Musique; nous aimons les Etrangers, nos les recevons le mieux que nous pouvons, nous voulons les amuser à quel prix que ce soit: ils sont accoutumés à la Musique Italienne, nos Compositeurs \& nos Virtuoses pour leur plaire s'italiénisent tant qu'ils peuvent; pour leur plaire encore davantage, nous saisons venir à grands frais des Virtuoses \& des Compositeurs Italiens, leur Opéra bouffon pour la seconde fois est placé à côté du spectacle le plus beau \& [28] les plus noble du monde: notre zele nous égare, nous avons toujours l'air de consulter les Italiens pour savoir comment il faut chanter le Franois; nous humilions \& nous décourageons nos Artistes; nous donnons aux Musiciens étrangers toutes les préférences \& toutes les récompenses: l'Académie François même, quoique tous ses membres sachent bien que le latin prononcé par un Italien n'est pas entendu à Paris, n'en a pas moins, pour faire sa cour aux étrangers, fait faire, l'année pasée, la Musique de son Motet par un Compositeur Italien ... Tous ces soins pour plaire aux étrangers gâtent nos oreilles, corrompent notre goût; affligent en secret l'ame de nos Compositeurs \& de nos Virtuoses, éteignent le feu de leur génie \& retardent les progrès de notre Musique ... Pour récompenser notre complaisance, quelques étrangers décrient notre Musique \& nos Artistes, s'imaginent que leurs productions valent plus que les nôtres, que leur Musique est universelle \& ils croyent que nous sommes trop heureux que leurs Musiciens veuillent bien venir nous instruire ...
Francoska ljubeznivost se dviga kot največja prepreka našega napredka $\mathrm{v}$ glasbi; radi imamo tujce, jih sprejemamo kot najbolje znamo, želimo jih razveseliti za vsako ceno: vajeni so italijanske glasbe, naši skladatelji in virtuozi se italijanizirajo, kolikor se le da, da bi jim ugajali; da bi jim ugajali še bolj, na velike stroške vabimo italijanske virtuoze in skladatelje, njihova komična opera je znova uvrščena med najlepše in najbolj veličastne predstave na svetu: zanos nas zavaja; vedno se zdi, da se posvetujemo z Italijani, kako je treba peti v francoščini; naše umetnike ponižujemo in jim jemljemo pogum; rajši imamo tuje umetnike, jih tudi nagrajujemo: celo francoska Akademija je, da bi ugajala tujcem, lani glasbo za motet naročila italijanskemu skladatelju, četudi njeni člani dobro vedo, da v Parizu ne razumejo latinščine, če jo izgovori Italijan ... Vsa ta skrb za užitek tujcev kvari naša ušesa, kvari naš okus; potihem prizadane dušo naših skladateljev in virtuozov, gaseč ogenj njihovega genija, in upočasnjuje napredek naše muzike ... Da bi nagradili našo ustrežljivost, nekateri tujci opisujejo našo glasbo in naše umetnike in si domišljajo, da so njihovi izdelki bolj vredni od naših, da je njihova glasba univerzalna, in verjamejo, da smo zelo srečni, ker so nas njihovi glasbeniki pripravljeni poučevati ...

Zanamci bodo bolj pravični do nas. Dobro bodo videli, da je samo želja ugajati tujcem tista, zaradi katere smo v svojem prvem liričnem gledališču trpeli italijansko opero buffo v času, ko v Nemčiji, Angliji in celo Italiji prevajajo naše očarljive komične opere. Zanamci ne bodo dvomili v naš ljubezniv značaj in prijateljskost, če bodo informirani o preferencah, ki jih namenjamo pevcem in pevkam iz Italije $\mathrm{v}$ času, ko obe naši operni hiši krasijo talenti, kot so Arnould, Duplant, Laguerre, 
La postérité nous rendra plus de justice, elle verra bien que c'est la seule envie de plaire aux étrangers qui a pu nous [29] déterminer à souffrir l'Opéra bouffon Italien sur notre premier Théâtre lyrique dans un tems où l'Allemagne, l'Angleterre \& l'Italie même traduisent nos charmans Opéra-comiques; elle ne doutera pas de notre caractère affable \& ami si elle est instruite des préférences que nous accordons aux Chanteurs \& Cantatrices d'Italie dans le tems où nos deux théâtres lyriques sont embellis par les talens distingués des Arnould, des Duplant, des Laguerre, des Levasseur, des Beaumesnil, des Duranci, des Girardin, des Joinville, des Larrivée, des Legros, des Moreau, des Lainé, des Colombe, des Billioni, des Caillot, des Clerval, des Nainviller, des Julien, des Michu, des Dorsonville, \& de beaucoup d'autres Artistes célebres des deux sexes, tous recommandables tant par leur chant que par leur jeu. Elle croira facilement que nous n'avions pas besoin des leçons de l'Italie dans le tems où brilloient en France le génie des Monsigni, des Gretry, des Philidor, des Gossec, des Floquet, \&c. où nos Orchestres étoient habituellement déservis par des Virtuoses, où on comptoit parmi nos Professeurs de Musique des hommes applaudis \& admirés dans toutes les [30] parties de l'Europe, même en Italie tant pour leur talent particulier, que pour leurs compositions. Mais ce que la postérité ne pourra jamais croire, c'est qu'il y avoit à Paris des connoisseurs que se sont laissés persuader quel'Opéra sérieux des Italiens pourroit faire fortune à côté de Castor EPollux, d'Ernelinde, de la Reine de Golconde, de Dabinus, de l'Union des Arts E de l'Amour, de Céphale E Procris, des deux Iphigénies, d'Orphée, de la nouvelle Armide, d'Alceste, du noveau Roland, \&c. \&c. Elle fera plus étonnée encore, si elle apprend que ces connoisseurs ont prétendu que le grand Opéra Italien pourroit bien dégoûter les François de leur manie de vouloir avoir un Opéra national.
Levasseur, Beaumesnil, Duranci, Girardin, Joinville, Larrivée, Legros, Moreau, Lainé, Colombe, Billioni, Caillot, Clerval, Nainviller,Julien, Michu, Dorsonville in še mnogi drugi sloviti umetniki obeh spolov, vsi po vrsti tako sijajni pevci kakor igralci. Zanamci bodo zlahka verjeli, da ne bi bili potrebovali učnih ur iz Italije v času, ko v Franciji živijo geniji, kot so Monsigni, Gretry, Philidor, Gossec, Floquet itn., ko so našim orkestrom skoraj vedno stregli virtuozi, ko naše profesorje glasbe častijo in občudujejo po vseh koncih Evrope, celo v Italiji - tako zaradi njihovega posebnega talenta kot zaradi njihovih skladb. Ampak kar zanamcem nikoli ne bo umljivo, je to, da obstajajo v Parizu poznavalci, ki so se pustili prepričati, da bi italijanska opera seria lahko ustvarila dobiček poleg takih del, kot so Castor et Pollux, Ernelinde, Reine de Golconde, Dabinus, L'Union des Arts E de l'Amour, Céphale et Procris, obe Iphigénies, Orphée, nova Armide, Alceste, novi Roland itn. itn. Zanamci bodo toliko bolj presenečeni, če bodo ugotovili, da ti poznavalci trdijo, kako naj bi italijanska velika opera mogla Francoze odvrniti od njihove obsedenosti, da želijo imeti svojo nacionalno opero. 
Navedeni odlomek, osrediščen v prepričanju o »naravnih vzrokih«, ki botrujejo prevladi italijanske glasbe po tedanji Evropi, s širokim čopičem nanaša drobce o kulturi, v kateri prevladuje prepričanje, "po katerem vse umetnosti držijo skupaj«, torej glasba ni posebna umetnost. Avtor se jasno postavi po robu takemu umevanju. Enako se Bemetzrieder zoperstavlja stališču tistih, ki dvomijo v vrednote nacionalnega glasbenega bogastva: okrca naivne mlade popotnike, ki da »opiti od zanesenjaštva«, užitega v Italiji, kjer da po božje častijo umetnike, prinašajo v Francijo tujerodne glasbene navade; opomni tudi slikarje, ki jim itak ni treba poznati vseh svetišč Apolona in se celo v nacionalnih simbolih poigravajo s tujimi vplivi; toži nad francosko ljubeznivostjo, ki da je kriva za francosko ksenofilijo, s katero jemljejo pogum in zanos domačim umetnikom; pokaže s prstom celo na francosko Akademijo, ki naroča italijanskim skladateljem slavnostne skladbe za državotvorne namene - in navaja vrsto glasbenikov in glasbenic, med katerimi so tudi taki, ki so še danes na zlatih straneh zgodovine glasbe Zahoda.

Da bi posodobili Bemetzriederjevo dikcijo, bi bilo treba zamenjati razloge za domnevno »slabo stanje«. Namesto občega prepričanja v enakost umetnosti, bi mogli za slabe glasbene navade kriviti ekonomska in kulturnopolitična prepričanja, ki resda govorijo o pospešeni splošni kvantitativni rasti izmenjave in kroženja kulturnih dobrin, a o nobenih kakovostnih spremembah v glasbenih praksah - glasba predstavlja »le« vodilno panogo in ne šteje za nikakršno posebno dejavnost. ${ }^{32}$ Ni mogoče spremeniti dejstva, da se funkcij glasbe ne da zvesti na posebno mesto človekovih dejavnosti, ker ima glasba zaradi svoje prežetosti z vsakdanjimi opravili docela navadno pozicijo, čeprav je danes mogoče govoriti bolj kot o rezultatih šele o začetkih sistematičnih študij o tem, katere so posebnost $i$ glasbe v primerjavi z drugimi umetnostmi. Nadalje bi mogli namesto »opitega zanesenjaštva«, ki ga spodbujajo prijetni ambienti v italijanskih glasbenih središčih, kriviti recimo dostopnost visoke tehnologije in obenem globalizacijo, ki »naivne mlade popotnike« zapeljuje k sprejemanju vsega, kar v»kulturnem gospodinjstvu«(T. W. Adorno) opremijo z nazivom glasba. Namesto slikarjev in kiparjev pa bi mogli opozoriti na dejstvo, da bi v Sloveniji težko našli poznavalca sodobne glasbe med sicer izjemnimi mojstri besede ali podob: «mimo poklicnih glasbenikov je malokdo seznanjen s sodobno glasbo, $« 33$ medtem ko imajo akademske glasbene ustanove predvsem posreden, večinoma pomanjkljivo koordiniran in po učinku razmeroma skromen vpliv na glasbene vrednote (prek javnih

32 Kvantitativni kazalci kulturnih dobrin »have increased five-fold over the last two decades« v primerjavi z desetletjema poprej. Med vsemi kulturnimi dobrinami pa "music goods continue to dominate the market (a quarter of all cultural imports and exports)《(Phillip Ramsdale, International flows of selected cultural goods 1980-1998, Unesco Institute for Statistics, Unesco Culture Sector, 2000, Preaface, ix). Dodati je treba, da so v primerjavi z drugimi kulturnimi dobrinami, med katere zgornji navedek iz UNESCOvega statističnega urada zajema - med drugim - tudi slikarstvo, film, šolstvo kakor tudi video kamere in šport, klasifikacije glasbenih dobrin nimajo posebnih statističnih obrazcev: statistike so izpeljane iz splošnih kulurno-socioloških študij.

33 Med ključnimi razlogi za slabo vpetost sodobne glasbe je morda smiselno omeniti tegale: ne gre za to, da bi najbolj zahtevni ustvarjalci v svojih delih ne bili pozorni na "gramatikaln[i] obču[e]k [..], ki bi glasbi vrnil nekaj izgubljene zmogljivosti govorice« (Intervju z Lojzetom Lebičem. Družina 1. 47, 7. - 15. 2. 1998, 16), temveč predvsem za prepro (heglovsko) dejstvo, da sočasnost različnega že zaradi količine ustvarjenega izmika tla pod nogami "herojski zgodovini« (T. W. Adorno) glasbe v smeri "osebnih resnic« (L. Lebič) in različnih "interesnih sfer $\mathrm{Z}$ besedami Črta Sojarja Voglarja iz promocijske brošure Društva slovenskih skladateljev bi torej danes lahko pozdravili dejstvo, da "raznolikost glasbenih stilov in estetik daje glasbi svojevrsten šarm in predstavlja neskončno bogastvo (Skladateljske sledi po letu 1900, Ljubljana 2003, np), čeprav bi se obenem kazalo vprašati, ali ni neskončnost bogastva neke vrste kulturna švedska miza, kjer si lahko vsak na krožnik nabere pač toliko, kolikor želi, a je zaradi dostopnosti vsega v neomejenih količinah obenem vse isto: $\mathrm{v}$ "neskončnem bogastvu « človekovega duha preprosto umanjka posebnosti, ker v svetu samih posebnosti pač ni prostora za neizmerljive posebnosti, obstajajo le primerljive. O teh seveda odločajo predvsem okus, interesi, kultura ali pa preprosto "družbeni domet" posamezne umenosti, in le v omejenem obsegu "neskončno bogastvo«, lastno njej ... 
ustanov, zlasti šolstva in nacionalne RTV, in nekaterih stanovskih društev, v Sloveniji zlasti Društva slovenskih skladateljev). Obenem pa bi mogli navesti vrsto izjemnih glasbenikov, ki v primerjavi s preteklimi obdobji tako po kakovosti kot količini ponujajo veliko več, ko je potrebno za institucionalizacijo glasbe kot posebne nacionalne umetnosti. Tudi Bemetzrieder priznava francoskim glasbenikom "narodotvorni« potencial, a vendarle predlaga ustanovitev nacionalnega glasbenega gledališča:

Nous sommes un peu extraordinaires dans ce siecle: les opinions démenties par l'expérience ne perdent pas le crédit parmi nous; l'Opéra-Bouffon devoit deux fois faire cette grande révolution; notre Opéra a triomphé chaque fois; mais on tient toujours aux opinions qu'on a légèrement adoptées, surtout quand on a quelques raisons pour leur être attaché; on persuade, sans être persuadé; on donne son avis laconiquement en maniere [31] de sentence; on paroît instruit \& pénétrent; les gens qui n'aiment pas l'examen, vous croient, \& donnent tort à l'expérience: si le grand Opéra Italien avoit trois fois ruiné la Ville, il y auroit encore à Paris de gens criant par-tout que nous n'avons pas l'idée de la Musique, que nous ne connoissons point le goût du chant, qu'il faut faire venir d'Italie les Compositeurs, les Cantatrices \& les Chanteurs.

N'étant pas del'avis de ces connoisseurs, je ne vais pas à une autre extrêmité; je ne pense pas que le mode françois soit le seul qui convient pour Paris; notre Capitale est la Capitale du monde, le mode Italien sur un théâtre séparé n'y seroit point déplacé: les Compositeurs de nos théâtres seroient même trés-bien de renforcer un peu leur expression \& de germaniser de temps en temps. Nous sommes blasés de Musique, la délicatesse ne fait plus qu'effleurer notre sentiment; il nous faut du sort ... D'ailleurs l'organisation de Paris est ajourd'hui necessairement vicieuse; les individus sont originaires des quatre parties du monde, \& toutes les organisations réunies font une organisation totale, qui tend à la dureté.
Malce nenavadni smo v tem stoletju: mnenja, ovržena z izkušnjo, med nami ne zgube veljave; opera buffa bi morala dvakrat napraviti to veliko revolucijo, a je vsakič zmagala naša opera. Toda danes se vedno prikimava stališčem, ki smo jih nalahko prevzeli, zlasti če imamo kakšen razlog, da smo nanje navezani. Prepričujemo, ne da bi bili sami prepričani; svoja mnenja podajamo strnjeno, v sentencah; zdimo se učeni in prodorni; ljudje, ki ne marajo preizpraševanja, verjamejo in zavračajo izkušnjo: če bi italijanska velika opera trikrat porušila mesto, bi še vedno v Parizu ljudje povsod kričali, da nimamo pojma o glasbi, da se ne spoznamo na pevski okus, in da je treba iz Italije pripeljati skladatelje, pevke in pevce.

Dasi ne sprejemam mnenja teh poznavalcev, ne grem v drugo skrajnost. Ne mislim, da se Parizu prilega samo francoska moda - naša prestolnica je prestolnica sveta in italijanska moda $\mathrm{V}$ ločenem gledališču ne bi bila neumestna: skladatelji naših gledališč celo ne bi storili napak, če bi nekoliko okrepili svoj izraz in se kdaj pa kdaj germanizirali. Glasbe smo prenasičeni, rahločutnost zgolj površno oplazi naša čustva; potrebujemo srečo ... Sicer pa je ureditev Pariza danes nujno sprijena. Posamezniki prihajajo z vseh koncev sveta in vse združbe skupaj tvorijo celotno strukturo, ki se nagiba k brezčutnosti.

Bralec, ki bo želel premisliti o tem stališču, bo sam dodal izpuščene argumente: njegovo stališče bo trdnejše - človek je pač 
Le lecteur qui voudra méditer cette [32] opinion, ajoutera de lui-même les argumens que j'omets: son opinion sera plus ferme; on est mieux persuadé, quand on y met du sien: $\&$, si j'ai beaucoup de Lecteurs, les ennemis du talent François ne parleront plus si haut; nos Musiciens pourront espérer le secours du zèle; ils trouveront des protecteurs; toutes les Musiques présentes \& futures auront des amis; par-tout on saura louer \& récompenser les Etrangers, sans dégoûter les Artistes du Pays.

Lu \& approuvé, ce 24 Septembre 1779. DE SAUVIGNY.

Vu l'Approbation, permis d'imprimer le 25 Septembre 1779. LENOIR. bolj prepričan, če sam doda nekaj svojega. In če imam veliko bralcev, sovražniki Francije ne bodo več tako glasni: naši glasbeniki bodo mogli upati na pomoč vneme; našli bodo zaščitnike; vse glasbe, zdajšnje in prihodnje, bodo imele prijatelje. Povsod bo mogoče najeti in nagraditi tujce, ne da bi omalovaževali umetnike domovine.

Bemetzriederjev predlog o ustanovitvi ločenega nacionalnega glasbenega gledališča v času, ko "posamezniki prihajajo z vseh koncev sveta in vse združbe skupaj tvorijo celotno strukturo, ki nagiba k brezčutnosti, « je kulturološka pragmatična rešitev nacionalnega vprašanja v glasbi. Zbirati, selekcionirati in posredovati na določen način to, kar je/tvori jedro identitete neke kulture, so osnovni mehanizmi uravnavanja »občega mnenja«. Te dejavnosti sodijo med temeljne vzvode tvorjenja identitete neke kulture, ki je y besedami Christiana Kadna »vor allem ein Meßfühler für soziales Wohlbefinden, für Lebenslust«, in "weniger ein spezifisch nationales oder ethnisches Phanomän, das was Eigenheiten, Eigen-wert, Eigen-tum begründet«..$^{4}$

$S$ predlogom o ustanovitvi nacionalnega glasbenega gledališča Bemetzriederjev spis preusmeri tok misli: vzpostavitve ustrezne nacionalne identitete ne išče več v glasbi sami, ne $\mathrm{v}$ antropoloških in ne kulturnih okoliščinah. Naslovi jo na institucionalne vzvode, ki - rečeno v duhu slovite misli Raymonda Wiliamsa, da "ni nobenih množic. Temveč le načini gledanja na ljudi kot množice ${ }^{35}$ - šele omogočajo neko opredelitev nacionalne identitete. Če je glasbeno gledališče v 18. stoletju nedvomno pravi naslov za tisti čas, bi danes kazalo poiskati institucionalni analogin $\mathrm{v}$ različnih ustanovah, kjer nacionalna kultura sploh dobi najširšo, celovito podobo. Na Slovenskem ze zdijo prizadevanja leta 2005 ustanovljenega Slovenskega glasbenoinformacijskega centra (SIGIC), ki meri na celovito beleženje glasbe na Slovenskem, ${ }^{36}$ usmerjena h kreiranju te podobe, čeprav tej ustanovi manjka »izvršilna« moč. Obstajajo seveda razlogi za ugovor tovrstni vzporednici.

34 Christian Kaden. Des Lebens Wilder Kreis. Musik im Zivilisationsprozeß. Op. cit., 226.

35 Raymond Williams. 'Kultura je navadna'. V: Raymond Williams. Navadna kultura. Izbrani spisi. Ljubljana: Studia humanitatis, $1997,15$.

36 SIGIC zbira podatke o individualnih in korporativnih avtorjih, o glasbenih delih in o glasbenih dogodkih (Zoran Krstulović, Struktura podatkovne zbirke Slovenskega glasbenoinformacijskega centra (SIGIC) in Merila za izbor podatkov (verzija 11.1.2004). 
Prvi v vrsti bi se lahko glasil: glasbenoinformacijski center ne zajema samo »nacionalne umetnosti«; gre v prvi vrsti za ustanovo, ki jo terja globalizacija. Na videz nacionalni glasbenoinformacijski center (razumljen seveda kot idealnotipska tvorba) ni neposredno vezan na vprašanje nacionalne identitete. A je ustanovitev tovrstnega regionalnega glasbenoinformacijskega središča neke vrste »izsiljena", četudi na videz povsem drugačna - sodobna, "tehnološka" - formalizacija "gradiva", k zbiranju in urejanju katerega so bila naravnana nacionalna kulturnoglasbena prizadevanja, o katerih govori tudi Bemetzrieder in ki so se začela oblikovati z "nacionalnim prebujejem« sredi 19. stoletja ter se utelesila na Slovenskem najprej z Glasbeno matico četrt stoletja kasneje, nadalje pa razvijala po različnih glasbenih ustanovah: v isti meri »hrani zgodovinski spomin« in po načelu vse v enem pušča prostor za oglaševanje vsega, kar zadeva glasbo. Mar nista koncentracija zgodovinskega spomina in $i / z$ biranje podatkov o nacionalnem kulturnem prostoru za najširši krog ljudi (kar je naloga nacionalnega glasbenoinformacijskega središča) enako učinkovito »orodje kulture« kot ustanovitev nacionalnega glasbenega gledališča v obdobju, ki se je vpisalo v glasbenozgodovinski spomin kot eno najbolj izrazito nadnacionalnih?

Pogojenost tvorjenja identitet omogoča premislek o zgoraj nakazani vzporednici med nacionalnim glasbenim gledališčem in nacionalnim glasbenoinformacijskim središčem, a nudi še večjo moč za njeno kritiziranje: gre za ustanovi z docela različnim ciljem; nadalje razlike v zgodovinskih okoliščinah ne dopuščajo tovrstne primerjave; in povrh učinkovitost prve in druge ustanove nikakor ni primerljiva (operna hiša ne nazadnje proizvaja »kulturne dobrine« v polnem pomenu besede, medtem ko informatizacija glasbenega okolja sama na sebi zgolj ponuja rezultate, informira, posreduje podatke o dosežkih in jih v najboljšem primeru komentira). Kljub vsekakor smiselnim ugovorom pa ne kaže spregledati primerljive funkcije obeh ustanov, ki bi jo mogli opredeliti kot točko "pragmatičnega esencializma" pri vzpostavljanju nacionalne glasbene identitete. Vzvodi, ki poganjajo tako nacionalno glasbeno gledališče kot nacionalno glasbenoinformacijsko središče, se enako spretno izognejo »substančnim« opredelitvam nacionalne identitete kakor tudi relativizirajočemu »relacijskemu« re/kontekstualiziranju nacionalnega: obema z geografsko »ozemljitvijo.«(Bemetzrieder celo svetuje francoskim skladateljem - Francozom po rojstvu -, naj se občasno "germanizirajo«, medtem ko glasbenoinformacijski centri posredujejo podatke o vseh glasbenih rečeh z nacionalnega, geografsko in politično zamejenega področja, ne glede na njihovo provenienco).

Sploh je Bemetzriederjev zadnji citirani odlomek poziv k pragmatičnemu, »življenjskemu u umevanju nacionalne identiete. Pogled je primerljiv s tistim, ki ga je pred nekaj leti izrekel slovenski filozof Tine Hribar: »Imeti nacionalno identiteto pomeni imeti lastno državo [...] od tod naprej pa je kajpada vse odprto. Z besedami Dušana Pirjevca, od nas je odvisno, kaj bomo naredili s samim seboj tudi na tej ravni, na ravni nacionalnosti. Ne absolutno, pa vendarle." (Hribar 2004: 416) ${ }^{37}$ Vezanost identitete na posamezne pojave - v večini primerov gre za jezik in geopolitični prostor - s pristavkom, da ne gre za absolutno, pač pa delno opredelitev identitete, odpira problematiko kontingence ali stičnosti pojavov, znotraj katere dobi vzporednica med Bemetzriederjevim predlogom o ustanovitvi nacionalnega gledališča in nacionalnega glasbenoinformacijskega sredi-

37 Tine Hribar. Evroslovenstvo. Ljubljana: Slovenska matica, 2004, 416. 
šča smisel. Za obe ustanovi je ključno, da - vsaka v svojem času na »državotvorni« ravni - posredujeta pojave na liniji: »Slovenec sem, torej je moje ustvarjanje slovensko« ${ }^{38} \mathrm{Za}$ obe ustanovi je bistvenega pomena to, da ne iščeta argumentov za nacionalno identiteto $\mathrm{v}$ "substanci« narejenega in niti v takšni ali drugačni mreži med seboj tesno stkanih določil nacionalnega: opirajo se na eno, edino merilo, in to je geografsko-politična danost - nacionalni prostor. Ključno je biti v njem, ne imeti kaj, kar ga ločuje od drugih (= "pragmatični esencializem»). Tovrstni "pragmatični esencializem« je očitno zgolj ena nit v vozlišču, kjer se oko ustavi na križišču povezav med deli in celoto, ki jo tvorijo: najsi gre za povzdigovanje nacionalne glasbene umetnosti z nekim univerzalističnim ciljem kakovosti pred očmi, kot pri Bemetzriederju, ali za zakoličevanje nacionalne glasbene kulture $\mathrm{z}$ namenom vključevanja $\mathrm{v}$ globalni pretok kulturnih dobrin, kot pri glasbenoinformacijskih središčih.

Vprašanje dela in celote je mogoče iz navedenega sklepnega odlomka Bemetzriederjevega spisa, kjer avtor strne v spisu vseskozi obravnavano tematiko nacionalnega kot nasprotja univerzalnega, razkriti, če ga beremo skozi dva vsebinska odtenka. Brati ga je mogoče pravzaprav samo na dva načina: kot poziv k iskanju medkulturnega ravnovesja po meri nacionalne »esence« ali kot ugotovitev stanja, kjer glasbene razlike porajajo neki »naravni vzroki« - razvoju glasbene umetnosti bolj in manj naklonjene okoliščine, značilne za posamezne nacionalne kulture. ${ }^{39}$

Vsak od obeh nakazanih načinov branja Bemetzriederjevega sklepa izhaja iz drugačnih spoznavnih domnev. Če bi ga brali kot predlog za vzpostavitev nacionalnega glasbenega jedra, bi kazalo nadalje odpreti humanistične in družboslovne teme: o nacionalni glasbeni substanci, o spodbujanju, institucionalizaciji in promoviranju določene kulturne prakse ipd. Če bi ga brali kot konstatacijo »naravnih vzrokov«za določeno stanje glasbene prakse, pa bi morali misel v nadaljnjem komentarju začrtati najprej vezi med humanistično razumljeno duhovno in intelektualno naravo človeka ter njegovimi naravoslovnimi, biološkimi in fiziološkimi pogojenostmi in njihovo vlogo v družbi. V obeh primerih bi morali opredeliti meddisciplinarne zahteve obravnave, o določenem vstavljanju nacionalne identitete med različne (pri Bemetzriederju med biofiziološke, osebnostne socio/psiholološke in kulturološke) spoznavne ravni, kjer bi morali (potihem ali izrecno) ponuditi neki raster spoznavnih ravni, kakršnega predlaga denimo Siegfried Mauser: ${ }^{40}$

38 Borut Loparnik. Biti skladatelj. Pogovori s Primožem Ramovšem. Ljubljana: Slovenska matica, 1984, 177.

39 Trditev izhaja iz naslednje interpretacije treh Bemetzriederjevih stališč iz zadnjega navedenega odstavka njegovega spisa. Zgodovina glasbe Zahoda ponuja bogat vir za dopolnjevanje Bemetzriederjeve osuplosti nad dejstvom, da »mnenja, ovržena z izkušnjo, med nami ne zgube veljave«: razžaloščenost »starih« nad "mladimi« v vrsti polemik glede premen v nova slogovna obdobja od antike naprej opozarja na bogastvo spremenljivk v odnosih med izkušnjo in veljavo. Nadalje: Bemetzriederjev nasvet, naj nacionalni skladatelji »okrepijo svoj izraz« in se celo kdaj pa kdaj germanizirajo«, sodi med krovno problematiko ne le glasbene postmoderne, glasb sveta in "glasbene globalizacije», temveč h ključnim vprašanjem o klasičnem v glasbi, kjer se tematika slogovnega prepletanja dviga na osrednje mesto obzorja, osrediščenega v domnevah o univerzalni estetski kakovosti. In še: Bemetzriederjevo trezno razumevanje glasbene prakse, srnjeno v napovedi, da bodo imele vse glasbe prijatelje, in želja po medkulturnem sožitju, kjer bo "mogoče najeti in nagraditi tujce, ne da bi omalovaževali umetnike domovine«, sodita ne le med ideale muzikološkega raziskovanja, ki meri na enakovredno obravnavo glasbenega univerzuma ne glede na provenienco ali pojavno obliko (najsi gre za slog ali družbeni status) določene glasbe, temveč k zdravorazumski glasbeni omiki, v kateri korenini znanost o "najbolj nedolžnem od vseh užitkov«.

40 Siegfried Mauser. 'Hermeneutik'. V: Ludwig Finscher (ur.), Musik in Geschichte und Gegenwart, Sachteil, Band 4, Kassel, Basel, London \& co.: Bärenreiter, 1996, 262-270. Podrobneje o hermenevtičnih ravneh raziskovanja glasbe prim. še: Leon Stefanija. 'Izhodišča hermenevtike glasbe: štirje pogledi'. V: Phainomena, 14/53-54 (november 2005), 229-264. 


\begin{tabular}{|l|c|c|c|}
\cline { 2 - 4 } \multicolumn{1}{l|}{} & $\begin{array}{l}\text { Avtor } \\
\text { [Autor] }\end{array}$ & $\begin{array}{l}\text { Tekst } \\
\text { [Text] }\end{array}$ & $\begin{array}{l}\text { Izvajalec-zvočni dogodek-poshušalec } \\
\text { [Aufführender-Klangereignis-Hörer] }\end{array}$ \\
\hline $\begin{array}{l}\text { Raven dejstev } \\
\text { [Ebene des Faktischen] }\end{array}$ & $\ldots$ & $\ldots$ & $\ldots$ \\
\hline $\begin{array}{l}\text { Raven intencionalnosti } \\
\text { [Ebene der Intentionalität] }\end{array}$ & $\ldots$ & $\ldots$ & $\ldots$ \\
\hline $\begin{array}{l}\text { Raven aktualizacije } \\
\text { [Ebene der Aktualisierung] }\end{array}$ & $\ldots$ & $\ldots$ & $\ldots$ \\
\hline $\begin{array}{l}\text { Raven zgodovinskosti } \\
\text { [Ebene der Geschichtlichkeit] }]\end{array}$ & $\ldots$ & $\ldots$ & $\ldots$ \\
\hline
\end{tabular}

Mauserjeva shema spodbuja vrsto pomislekov na račun spoznavne utemeljenosti Bemetzriederjevega spisa. Na primer, če je Bemetzriederjevo povzdigovanje italijanske glasbe in tematiziranje nacionalnih razlik mogoče sprejeti kot zgodovinsko dejstvo glede avtorstva, se njegova znanstveno zastavljena argumentacija esejistično posploši že na ravni teksta, zlasti pa na recepcijski ravni, ki zahteva opredelitev podrobnosti v nizu »izvajalec-zvočni dogodek-poslušalec«: osrednji del argumentacije spisa temelji na biofizioloških določilih, ki jih začrta z vzporednico med glasbo in jezikom, medtem ko nadaljnje izvajanje docela obide vlogo in pomen teh »tekstovnih" gradnikov nacionalnega - avtor nadaljuje s posplošeno kulturološko kritiko sklicujoč se na družboslovno pogojene "naravne razloge« za ugotovljeno stanje. Ne ponuja odgovora na sicer edini logični sklep, ki bi moral slediti njegovi trditvi, da je vsakemu narodu bližja glasbena dikcija, ki ustreza njegovemu biofiziološkemu profilu, utelešenem v »vzvišenih čudesih poezije« jeziku: Bemetzriederjevo besedilo napeljuje k sklepu, da je bio-fiziološka podstat, ki naj bi izhajala iz vrojenega učinka »najlepšega jezika Evrope«, družbeno nekako zatajila v primerjavi s kulturno veljavo tiste, ki jo avtor pripisuje predvsem italijanski glasbi.

Seveda bi mogli upravičeno ugovarjati, da je povsem neumestno kritizirati Bemetzriederjevo sicer tehtno pričevanje o zgodovinskih okoliščinah s tovrstnim silogizmom, ki meri na domnevno neskladje med podatki in dejstvi: ${ }^{41}$ glede na »budniški« namen Bemetzriederjevega spisa in okoliščine raziskovanja glasbe ob koncu 18. stoletja je njegovo besedilo več kot tehtna razprava, ki se ukvarja tako z biofiziološkimi temelji kot kulturnimi vrednotami glasbe; povrh je nemogoče začrtati nacionalno identiteto drugače kot s sopostavljanjem »substančnih« in »relacijskih" brvi med spremenljivim pojmovanjem nacionalnega. Z izrazom občudovanja Bemetzriederjevega spisa, ki mu nikakor ne moremo odrekati spoznavne vrednosti, moram zato poudariti, da je zgornja »kritika« spoznavne utemeljenosti spisa Glasbena toleranca ob Mauserjevi shemi spoznavnih ravni mišljena kot pogled s točke, ki vrača misel k uvodoma začrtanemu izhodiščnemu stališču celotnega prispevka - k delitvi muzikoloških prizadevanj po dveh medsebojno povezanih koordinatah (poenostavljeno rečeno): metodološki in slogovni.

Pogled na izhodiščno delitev namreč z namerno poenostavljeno idealnotipsko delitvijo muzikoloških prizadevanj postavlja v ospredje vprašanje o razmerju med metodološko različno pogojenimi ravnmi spoznanja, kjer je identiteta glasbe bodisi vstavljena med kulturološke relacije kodificiranja identitet glasbe, in njej lastna substančna, "slogovna" določila. Kaj muzikologija danes ponuja za razumevanje razmerja, kjer se glasbeno-

41 Razliko povzemam po študiji Grudlagen der Musikgeschichte Carla Dahlhausa, kjer opozarja na eno osnovnih zgodovinopisnih vodil, po katerem je treba ločevati med dokumenti ali podatki in pa ugotovitvijo dejstev, ki jih zgodovinar izpelje na podlagi dobljenih podatkov. (Pozveto po ang. Prev. J. B. Robinsona, Foundations of Music History. Oxford: Oxford University Press, str. 34 in naprej.) 
nacionalne »substance« križajo, prepletajo, dopolnjujejo, krepijo ali slabijo, skratka spreminjajo spričo glasbenih »dejavnosti« ali glasbene prakse ${ }^{42}$ - kjer torej ne gre le za določila glasbene pomenskosti, temveč tudi široke palete učinkovnosti glasbe?

Vprašanje je preširoko, da bi bilo smiselno iskati odgovor, in obenem preveč pomembno, da bi ga pustili ob strani. Ne gre namrečle za spoznavoslovno zapuščino Bemetzriederjevega besedila, ampak obenem za eno osrednjih muzikoloških vprašanj: o moči glasbe in vplivnosti neglasbenega nanjo. Gre za vprašanje, ki obe pri Bemetzriederju vsebovani usmeritvi diskusije, »substancialistično«(glasba in jezik) in kulturološko (glasba in »naravni vzroki«), naslavljata na spoznavni aparat, s pomočjo katerega bi bilo mogoče zapolniti Mauserjevo zgoraj navedeno shemo spoznavnih ravni tako, da bi bilo mogoče jasno opredeliti razmerja med pomenskostjo teksta in spremenljivkami recepcije le-tega. ${ }^{43} \mathrm{Na}$ teoretski ravni gre torej za »medpodročno kartografiranje« (ali opisno: »vrisovanje področij za glasbene pojave»), kot bi mogli posloveniti »cross-domain mapping«, enega osrednjih glasbenoteoretskih spoznavoslovnih konceptov izpod peresa Lawrencea M. Zbikowskega, ${ }^{44} \mathrm{~s}$ katerim avtor predlaga formalizacijo sicer prastare muzikološke usode povezovanja glasbenih pojavov v neko razumljivejšo in celovitejšo spoznavno podobo z dvema glavnima namenoma pred očmi: "First, it provides a way to connect musical concepts with concepts from other domains. [...] Second, cross-domain mapping allows us to ground our descriptions of elusive musical phenomena in concepts derived from everyday experience $\ll .{ }^{45}$

Sevedabrez konkretnih primerov ni mogoče govoriti o tovrstnem spoznavnem o(g)rodju, zlasti še, ker Zbikowski obravnava proces "medpodročnega kartografiranja» predvsem na ravni kognicije glasbenih struktur, ne o "zarisovanju njihovih učinkov v različna interpretativna besedišča. Mogoče pa ga je začrtati v obliki povzetka raziskav, ki o identiteti glasbe govorijo prek opredelitev njenih funkcij - z vokabularjem kognitivno-recepcijskih vrednot, ki jih učinkom glasbi pripisujejo različna disciplinarna gledišča, kot nakazuje naslednja dopolnitev prikaza, ki sta ga ponudila Radocy in Boyle (Radocy / Boyle 2003:10-19, 32-3): ${ }^{46}$

42 Prim. Dalibor Davidović. Identität und Musik. Zwischen Kritik und Technik. Wien: Mille Tre Verlag Robert Schächter, 209-215.

43 Na tem mestu kaže omeniti prizadevanja dveh raziskovalnih usmeritev. Na eni strani se uveljavlja raziskovanje zvočnih posnetkov, kjer pod vodstvom Nicholasa Cooka ustanovljenega Research Centre for the History and Analysis of Recorded Music (CHARM) vrsta odmevnih muzikologov pomika »objekt« raziskovanja glasbe stran od analize notnega zapisa v smeri raziskovanja recepcije. (Podobno narašča zanimanje za analizo izvajalske prakse, o čemer izčrpno govori npr. Alf Gabrielson. 'Music Performance Research at the Millenium'. V: Psychology of Music, Vol. 31 / No. 3 \{2003\}, 221-272.) Po drugi plati pa se zlasti s področja psihologije glasbe pojavljajo vredni predlogi po bio-, fizio- in nevroloških študijah glasbe, ki odpirajo možnosti raziskavam recepcije glasbe na način in z raziskovalnim aparatom, ki ga humanistične vede doslej niso posebej razvijale, razen seveda v okviru psihologije glasbe. Čeprav z obeh smeri prihaja vedno več predlogov za inkluzivne, dopolnjujoče meddisciplinarne študije pa se zdi, da meddisciplinarnost pri raziskovanju glasbe za zdaj ostaja bolj na deklarativni in manj na eksplicitni ravni.

Lawrence M. Zbikowski's Conceptualizing Music. Cognitive Structure, Theory, and Analysis. Oxford: Oxford University Press 2002, esp. $63 \mathrm{ff}$.

45 Prav tam, 76

46 Rudolf E. Radocy / Boyle J. David. Psychological Foundations of Musical Behaviour. Illinois: Charles C Thomas Publisher LTD, 2003. - Allan P. Merriam. The anthropology of music. Evanston: Northwestern University Press 1964/1980, 222-227. - Thayer E. Gaston. Man and Music. (E.T. Gaston, Ed., Music In Therapy). New York: The MacMillan Company 1968, 21 in naprej. - KlausErnst Behne. Hörertypologien. Zur Psychologie des jugendlichen Musikgeschmacks. Regensburg: Gustav Bosse Verlag, 1986. Vladimir Karbusicky. 'Gegenwartsprobleme der Musiksoziologie'. V: Acta musicologica Vol. LVIII, 1986: Fasc.I, 35-91. - Simon Frith. 'Toward an aesthetics of popular music'. V: Richard Leppert \& Susann McClary (Eds.). Music and society. Cambridge: Cambridge University Press 1987, 140-144. - Max Kaplan. The arts: A social perspective. Rutheford: Fairleigh Dickinson University Press 1990, 18 in naprej. - Richard Middleton. Studying Popular Music. Philadelphia: Milton Keynes. Open University Press 1990, 253. - Andreas C. Lehmann. 'Habituelle und situative Rezeptionsweisen beim Musikhören im interkulturellen Vergleich'. In: Musikpsychologie: Jahrbuch der Deutschen Gesellschaft für Musikpsychologie 10 (1993): 38-55. - D. J. Hargreaves / A. C. North. 'The functions of music in everyday life: redefining the social in music psychology.' Psychology of Music, 27/71 (1999), 71-83. - Bruno Nettl. ,An Ethnomusicologist Contemplates Unievrsals in Musical Sound and Musical Culture'. In: Wallin, Niels L. / Merker Björn / Brown, Steven (Eds.). The Origins of Music, Cambridge, Massachusetts, London: MIT Press 2001, 463-472. 


\begin{tabular}{|c|c|c|c|c|c|c|c|c|c|}
\hline $\begin{array}{l}\text { Merriam } \\
1964\end{array}$ & $\begin{array}{l}\text { Gaston } \\
1968\end{array}$ & Behne 1986 & \begin{tabular}{|l} 
Karbusicky \\
1986 \\
(po: Paul F. \\
Lazarsfeld's \\
/ RobertK. \\
Merton: Mass \\
Communication, \\
Popular Taste, and \\
Organized Social \\
Action [1948/60] \\
oz. Alfons Auer's \\
Ethos der Freizeit \\
[1972]) \\
\end{tabular} & $\begin{array}{l}\text { Frith } \\
1987\end{array}$ & Kaplan 1990 & $\begin{array}{l}\text { Middleton } \\
1990\end{array}$ & $\begin{array}{l}\text { Lehmann } \\
1996\end{array}$ & $\begin{array}{l}\text { Hargreaves \& } \\
\text { North } 1999\end{array}$ & $\begin{array}{l}\text { Nettl } \\
2001\end{array}$ \\
\hline \begin{tabular}{|l|} 
emotional \\
expression
\end{tabular} & \begin{tabular}{|l} 
a need for \\
aesthetic \\
expression and \\
experience
\end{tabular} & $\begin{array}{l}\text { motorisches } \\
\text { Hören }\end{array}$ & $\begin{array}{l}\text { Regenerative } \\
\text { Funktion }\end{array}$ & \begin{tabular}{|l|} 
helps to create \\
a type of \\
self-definition, a \\
particular place in \\
society
\end{tabular} & $\begin{array}{l}\text { a form of } \\
\text { knowledge }\end{array}$ & $\begin{array}{l}\text { Communicative } \\
\text { values }\end{array}$ & ease/ relax & $\begin{array}{l}\text { management of } \\
\text { self-identity }\end{array}$ & $\begin{array}{l}\text { use in rituals } \\
\text { and addressing } \\
\text { supernatural }\end{array}$ \\
\hline $\begin{array}{l}\text { aesthetic } \\
\text { enjoiment }\end{array}$ & \begin{tabular}{|l|} 
determinants of \\
the cultural matrix \\
on the mode of \\
expression
\end{tabular} & $\begin{array}{l}\text { compensatorisches } \\
\text { Hören }\end{array}$ & $\begin{array}{l}\text { Emanzipatorische } \\
\text { Funktion }\end{array}$ & $\begin{array}{l}\text { provides a way } \\
\text { of managing } \\
\text { the relationships } \\
\text { between one's } \\
\text { private and public } \\
\text { emotional lives }\end{array}$ & $\begin{array}{l}\text { collective } \\
\text { posession }\end{array}$ & Ritual values & associate / dream & \begin{tabular}{|l|} 
interpersonal \\
relations
\end{tabular} & $\begin{array}{l}\text { "transforming } \\
\text { experience"(David } \\
\text { McAllester): } \\
\text { changes } \\
\text { "individual's } \\
\text { consciousness" or } \\
\text { "ambience of a } \\
\text { gathering" } \\
\end{array}$ \\
\hline entertainment & $\begin{array}{l}\text { integrational } \\
\text { relationship } \\
\text { between music } \\
\text { and religion }\end{array}$ & vegetatives Hören & $\begin{array}{l}\text { Kompensatorische } \\
\text { Funktion }\end{array}$ & $\begin{array}{l}\text { helps to shape } \\
\text { memory, organize } \\
\text { onés sense of } \\
\text { time, and intensify } \\
\text { experiences }\end{array}$ & $\begin{array}{l}\text { personal } \\
\text { experience }\end{array}$ & Technical values & escapistic stimulus & mood & $\begin{array}{l}\text { marking } \\
\text { importance of } \\
\text { events }\end{array}$ \\
\hline communication & $\begin{array}{l}\text { music as } \\
\text { communication }\end{array}$ & diffusives Hören & \begin{tabular}{|l} 
(status conferral \\
function)
\end{tabular} & $\begin{array}{l}\text { provides a sense } \\
\text { of musical } \\
\text { ownership }\end{array}$ & therapy & Erotic values & \begin{tabular}{|l} 
identity \\
determining \\
stimulus
\end{tabular} & & $\begin{array}{l}\text { Association with } \\
\text { dance }\end{array}$ \\
\hline \begin{tabular}{|l} 
symbolic \\
representation
\end{tabular} & $\begin{array}{l}\text { music as } \\
\text { structured reality }\end{array}$ & $\begin{array}{l}\text { emotionales } \\
\text { Hören }\end{array}$ & $\begin{array}{l}\text { (narcotizing } \\
\text { dysfunction) }\end{array}$ & & $\begin{array}{l}\text { moral and } \\
\text { symbolic force }\end{array}$ & Political values & \begin{tabular}{|l|} 
sentimentality \\
arousing stimulus
\end{tabular} & & \\
\hline physical response & \begin{tabular}{|l|} 
music's \\
relationship to the \\
tender emotions
\end{tabular} & $\begin{array}{l}\text { sentimentales } \\
\text { Hören }\end{array}$ & $\begin{array}{l}\text { (reinforcement } \\
\text { function) }\end{array}$ & & \begin{tabular}{|l|} 
incidental \\
commodity
\end{tabular} & & $\begin{array}{l}\text { emotion / mood } \\
\text { stimulation }\end{array}$ & & \\
\hline $\begin{array}{l}\text { enforcement of } \\
\text { conformity to } \\
\text { social norms }\end{array}$ & $\begin{array}{l}\text { a source of } \\
\text { gratification }\end{array}$ & assoziatives Hören & & & $\begin{array}{l}\text { symbolic indicator } \\
\text { of change }\end{array}$ & & arousing senses & & \\
\hline \begin{tabular}{|l|} 
validation of social \\
institutions and \\
religious rituals
\end{tabular} & \begin{tabular}{|l|} 
potency of music \\
(in a group)
\end{tabular} & $\begin{array}{l}\text { distanziertes } \\
\text { Hören }\end{array}$ & & & $\begin{array}{l}\text { link among past, } \\
\text { present, and } \\
\text { scenarios of the } \\
\text { future } \\
\end{array}$ & & \begin{tabular}{|l|} 
background \\
stimulus
\end{tabular} & & \\
\hline $\begin{array}{l}\text { contributes to } \\
\text { the continuity } \\
\text { and stability of } \\
\text { culture } \\
\end{array}$ & & & & & & & \begin{tabular}{|l|} 
consoling / \\
compensating \\
stimulus
\end{tabular} & & \\
\hline $\begin{array}{l}\begin{array}{l}\text { contributes to } \\
\text { the integration of } \\
\text { society }\end{array} \\
\end{array}$ & & & & & & & & & \\
\hline
\end{tabular}

V opredelitvah glasbenih funkcij različna določila funkcij glasbe - sociološka in kulturološka (na primer pri Meriamu ali Middletonu), antropološka (kot pri Karbusickem, Kaplanu ali Nettlu), sociopsihološka (kot pri Hargreavesu in Northu) ali pa psihološka (kot pri Lehmannu) - nedvomno pričajo o učinku glasbe, ki odpira problematiko pripadnosti k določeni družbeni skupini. Toda če družbena učinkovnost glasbe ni dvoumna, ostaja vprašanje ločnic med njenimi družbenimi učinki docela odprto. Odprto ne ostaja 
samo na liniji lokalno - regionalno - etnično - narodno - nacionalno - nadnacionalno, temveč na ravni "pretvarjanja narave glasbe in njenega učinka na posameznika v kulturne vrednote glasbe, v »skupne učinke«. Ne nazadnje se kaže vprašati: na kateri točki Möbiusovega traku funkcij glasbe spodaj (izpeljan je iz petih osrednjih funkcijskih tipov iz zgornje preglednice), s kakšnimi nameni, vzvodi ipd. je treba glasbo prikazati kot »simbolično reprezentacijo« (Meriam) nacionalnega in v kakšnem razmerju so si med seboj različne funkcije, kot so »vzbujanje čutov« (Lehmann), »transformirajoča izkušnja» (Nettl), »strukturiranje realnosti« (Gaston), »medosebna razmerja» (Hargreaves in North) ter »simbolična reprezentacija« (Merriam)?

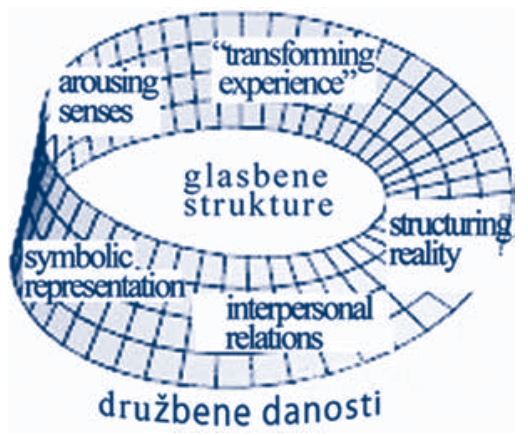

Möbiusov trak funkcij glasbe

Odgovor je seveda mogoče ponuditi za posamezne konkretne primere. Na empiričen način je mogoče nakazati nacionalne razlike med skladatelji, kot je to denimo storil Fred Hofstetter za komorno glasbo francoskih, nemških, čehoslovaških in ruskih skladateljev 19. stoletja. ${ }^{47}$ A medtem ko je Hofstetter začrtal izrazitost nacionalnega odtisa v glasbi (kot vodilne je izpostavil ruske skladatelje), na vprašanje o prevladi določene nacionalne glasbe danes domala ni odgovora. Ne nazadnje: v obdobju globaliziranja in pospešenega kulturnega pretoka je tak odgovor težko pričakovati (in bi verjetno tudi zvenel enako sumljivo kot kaka skrajnost »vulgarnega idealizma« \{J. Vogrinec $\}$, denimo tista, da je vse zgolj sociološko konstrukcijo resničnosti). Toda: je ta pretok drugačen od tistega, ki ga v svoj spis vključuje Bemetzrieder?

Četudi je, obstajajo razlike in stičnice. Če je Bemetzrieder v Glasbeni toleranci podal razloge (s pojmi iz Möbiusovega traku zgoraj) za simbolno reprezentacijo nacionalnega v glasbenih strukturah s pomočjo paralele med glasbo in jezikom in s »kulturološkim« orisom glasbene prakse podal relevantno stališče glede prevlade italijanske, bi danes terjala tovrstna trditev, če bi jo bil kdo pripravljen resno izreči, ne le neki konsenz o človekovih "možganih za glasbo « ${ }^{48}$ temveč raziskavo glasbenih navad, kakršno sociolog Geert Hofstede od sedemdesetih let naprej izvaja za »kulturne dimenzije«v vrsti

\footnotetext{
47 Fred Hofstetter. 'The nationalist fingerprint in nineteenth-century chamber music'. V: Computer and the Humanities 13 (1979), 105-119.

48 Daniel J. Levitin. This is your Brain in Music. Op. cit.
} 
nacionalnih okolij po svetu: ${ }^{49}$ raziskovalec bi moral glasbene strukture in nanjo vezane družbene vrednote primerjalno analizirati na velikem vzorcu poslušalcev, glasbenih programov, medijev, skratka na množici glasbenih ustanov in med njimi vzpostaviti določeno hierarhijo. ${ }^{50}$ Toda: čemu?

Podobno kot se Mladen Dolar v uvodoma omenjenem članku ${ }^{51}$ postavlja v vlogo razumevajočega sopotnika različnih glasb, bi se na tej točki kazalo postaviti v vlogo zagovornika potrebe in možnosti iskanja spoznavnih vzvodov, ki so značilni za Bemetzriederjevo Glasbeno toleranco in tudi obe nakazani usmeritvi sodobnih muzikoloških raziskav, slogouno in metodološko.

Ko Bemetzrieder govori o toleranci med nacionalnimi glasbami in utemeljuje nacionalno z analogijo med glasbo in jezikom kot človeškim biofiziološkima refleksoma, toda razlog za toleranco - neutemeljena prevlada italijanske glasbe - ponudi tako rekoč s šopkom bodičastih kulturoloških interpretacij o zanj »naravnih vzrokih" glasbene prakse. Pri tem ne dvomi, da vsaka od nacionalnih glasb ima (ali pa lahko doseže) nekaj, kar si zasluži laskave prilastke najboljšega, zglednega, najurednejšega, celo klasičnega, da lahko vsaka nacionalna glasba doseže raven, ki bi se mogla vpisati med univerzalne dobrine v tradiciji glasbe Zahoda. Z enako vnemo je mogoče spremljati muzikološka prizadevanja danes - najsi gre za slogovna ali metodološka vprašanja -, ki skušajo priti do "comprehensive theory«, s katero bi bilo mogoče temeljito obravnavati "the more synthetic character of music «. 52

Toda na tej točki - na točki opredelitve »bolj sintetičnega značaja« glasbe, ki sodi med aksiome tako semiotikov, hermenevtikov, zgodovinarjev in kulturologov glasbe kot raziskovalcev kognitivnih in nevroloških plati glasbenega učinka - se Bemetzriederjev spis o glasbeni toleranci, kjer tvega tako "naravoslovno« kot »kulturološko» opredelitev nacionalne glasbe, kaže v tretji, "zgodovinsko uporabni« luči: kaže se eden zgodnejših glasbenozgodovinski spisov, kjer avtor skuša »to tell an uninterrupted story, from patterns of the objective world, through imperfectly learned heuristics used for predicting that world, to the phenomenal qualia we experience as we apprehend the world «. Četudi je stavek izrečen pred dobrim letom v meddisciplinarni, v primerjavi z Bemetzriederjevim spisom povsem drugačni študiji s področja psihologije glasbe Davida Hurona, ${ }^{53}$ zajema enako obzorje glede določevanja identitete glasbe, kot ga nakazuje spis

49 Hofstedejeve sociološke dimenzije kulture so: bližina moči (power distance; enakost-neenakost med ljudmi v neki deželi), individualizem (individualism; medosebna razmerja, individualizem in kolektivizem), moškost (masculinity; vloge spolov in vprašanje moči); stopnja negotovosti (uncertainty avoidance; stopnje toleriranja negotovosti in nejasnosti), in dolgoročna naravnanost (long-term orientation; dolgoročna naklonjenost k določenim družbenim vrednotam). Geert Hofstede. Culture's Consequences: International Differences in Work-Related Values. Beverly Hills, California: Sage Publications, 1980. Za revidirani pogled na projekt gl.: Geert Hofstede / Robert R. McCrae. 'Personality and Culture Revisited: Linking Traits and Dimensions of Culture'. V: Cross-Cultural Research, Vol. 38 / No. 1 (February 2004), 52-88.

50 V izogib nesporazumom: obstaja vrsta raziskav o učinkih glasbe in o glasbenih navadah tako v posameznih kulturnih okoljih kot v kulturno "odprtih" prostorih modernega vsakdanjika (npr. D. J. Hargreaves / A. C. North. "The functions of music in everyday life: redefining the social in music psychology'. V: Psychology of Music, $27 / 71,71-83$. Ali pa: Tia DeNora. Music in Everyday Life. Cambridge: Cambridge University Press 2000.) Kljub vrsti parcialnih študij o glasbenih praksah, ki jih v zadnjem desetletju spodbuja tudi v raziskavah glasbe priljubljena sociološka usmeritev pod pragmatično oznako "urbane študije» (»urban studies«), pa bi težko govorili o možnostih za argumentirano razpravo o procesih, ki očitno vseskozi prinašajo živahne spremembe v prevladah posameznih glasbenih struktur.

51 Mladen Dolar. 'Function beyond function? Reflections on the functionality of the autonomous'. Op. cit.

52 Robert Hatten. 'Four Semiotic Approaches to Musical Meaning: Markedness, Topics, Tropes, and Gesture'. Op. cit, 5-30.

53 David Huron. Sweet anticipation. Music and the Psychology of Expectation. Cambridge, Massachusetts, London, England: The MIT Press, 2006, viii. 
Glasbena toleranca: isto prizadevanje po povezovanju razumevanj glasbe kot fizičnega in duhovno-kulturnega.

V obeh primerih - v razpravi o nacionalni glasbi s konca 18. stoletja, o kateri govori Bemetzrieder, in muzikoloških študijah ob prelomu v 21. stoletje, ki so nakazane v komentarjih - ne gre za formalne oziroma metodološke pomankljivosti, ki bi jih bilo treba tolerirati. Verjetno je (bila) toleranca v obeh primerih - pri vključevanju in spoštovanju različnih (nacionalnih) glasb v muzikološko obzorje v enaki meri kot pri povezovanju različnih ravni razumevanja glasbe v odbobju, ki brez glavnega vhoda v neko specifično muzikološko spoznavno teorijo terjajo analitično učinkovitost - eno osrednjih sporočil v steklenici Bemetzriederjevega spisa. Bralca namreč postavlja pred dejstvo, da kulturna vrednost glasbe (najsi nacionalna ali katera koli druga) ni le funkcionalistična in (po Bemetzriederju v pretežni meri) idealistična, kot podoba vseh mogočih najstev, ki se jih glasbi pripisuje, pač pa tudi povsem elementarno pogojena v določenih bioloških, univerzalnih, »fizikalističnih" plateh človeka. Precejšna mera pragmatičnega sopostavljanja dejstev in podatkov o nacionalni identiteti, v katerega je vpet Bemetzriederjev poziv h glasbeni toleranci, se zdi še posebej vredno znamenje za premislek o vlogi tolerance danes. Vedi o »najbolj nedolžnem vseh užitkov«, ki ob tu nakazanih spoznavoslovnih trenjih in komajda pregledni množici simpatij do različnih glasb skuša zajeti privlačno podobo glasbe, ki je od nekdaj živela na dveh bregovih, znanstvenem in umetniškem, je toleranca seveda potrebna tudi danes. Glede na nekatera v tem prispevku omenjena muzikološka prizadevanja, ki po zamislih tako rekoč s polnimi pljuči črpajo iz duha svojega časa, se je vredno vprašati še, katere druge elementarne spoznavne drže mimo tolerance vodijo $\mathrm{k} »$ napredku glasbe svoje dobe». 